\title{
A Physiologically Explicit Morphospace for Tracheid-based Water Transport in Modern and Extinct Seed Plants
}

\section{Citation}

Wilson, Jonathan P., and Andrew H. Knoll. 2010. A physiologically explicit morphospace for tracheid-based water transport in modern and extinct seed plants. Paleobiology 36(2): 335-355.

\section{Published Version}

doi:10.1666/08071.1

\section{Permanent link}

http://nrs.harvard.edu/urn-3:HUL.InstRepos:4795216

\section{Terms of Use}

This article was downloaded from Harvard University's DASH repository, and is made available under the terms and conditions applicable to Open Access Policy Articles, as set forth at http:// nrs.harvard.edu/urn-3:HUL.InstRepos:dash.current.terms-of-use\#OAP

\section{Share Your Story}

The Harvard community has made this article openly available. Please share how this access benefits you. Submit a story.

Accessibility 
Wilson - 1

A Physiologically Explicit Morphospace for Tracheid-Based Water Transport in Modern and Extinct Seed Plants

Jonathan P. Wilson*

Andrew H. Knoll

September 7, 2009

\section{RRH: PHYSIOLOGICALLY EXPLICIT MORPHOSPACE}

LRH: JONATHAN P. WILSON AND ANDREW H. KNOLL 


\section{$\underline{\text { Abstract }}$}

We present a morphometric analysis of water transport cells within a physiologically explicit three-dimensional space. Previous work has shown that cell length, diameter, and pit resistance govern the hydraulic resistance of individual conducting cells; thus, we use these three parameters as axes for our morphospace. We compare living and extinct plants within this space to investigate how patterns of plant conductivity have changed over evolutionary time. Extinct coniferophytes fall within the range of living conifers, despite differences in tracheid-level anatomy. Living cycads, Ginkgo biloba, the Miocene fossil Ginkgo beckii, and extinct cycadeoids overlap with both conifers and vesselless angiosperms. Three Paleozoic seed plants, however, occur in a portion of the morphospace that no living seed plant occupies. Lyginopteris, Callistophyton, and, especially, Medullosa evolved tracheids with high-conductivities similar to those of some vessel-bearing angiosperms. Such fossils indicate that extinct seed plants evolved a structural and functional diversity of xylem architectures broader, in some ways, than the range observable in living seed plants.

Jonathan P. Wilson *. Department of Earth and Planetary Sciences, Harvard University, Cambridge, Massachusetts 02138.

Andrew H. Knoll. Department of Organismic and Evolutionary Biology, Harvard University, Cambridge, Massachusetts 02138.

* Present address: Division of Geological and Planetary Sciences, California Institute of Technology, Pasadena, California 91125. Email: jpwilson@caltech.edu 


\section{Introduction}

Extant plants, particularly conifers and angiosperms, have evolved two distinct ways to achieve low-resistance water transport in their vascular systems: the vessel and the torus-margo pit. Vessels are often wide (up to $500 \mu \mathrm{m})$, long ( $>1 \mathrm{~m})$, multicellular tubes that allow water to be transported long distances without flowing through a cell wall. They are characteristic of angiosperms, and occur, as well, in a few ferns and gymnosperms. The torus-margo pit, a highly porous valve that greatly reduces the hydraulic resistance to flow between tracheids, is characteristic of conifers and Ginkgo. Do these strategies exhaust the ways that seed plants can reduce flow resistance through the xylem, and if not, why do they predominate among living plants?

To address these questions, we constructed a three-dimensional morphospace of xylem cells in which each axis has a discrete anatomical range, creating a space within which every point has quantitative physiological meaning. This morphospace provides a framework for the structural and functional comparison of living and extinct seed plants. We modeled fluid flow in xylem cells of twenty-two living plants and six extinct taxa:

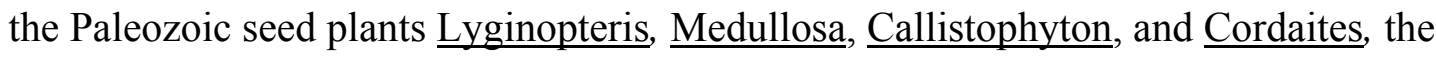
Mesozoic seed plant $\underline{\text { Cycadeoidea, }}$ and the Miocene Ginkgo beckii. Our conclusion that fundamental differences exist in the occupation of conductivity space between the Paleozoic and the Recent has important consequences for interpreting the evolutionary and functional trajectories of seed plant wood.

\section{Background}


Living seed plants have converged upon two dominant forms of wood anatomy, based on differing ways of balancing structural support and high-throughput water transport. Angiosperms exhibit a division of labor in the xylem, whereby most cells derived from the vascular cambium fulfill one of two functions: structural support, in the form of long, thin, highly lignified and nonconducting cells called fibers, and transport, in the form of vessels, which are long, wide, multicellular conduits.

Conifers, on the other hand, rely on short, narrow tracheids for both water transport and structural support—achieving increased throughput of water by means of highly porous torus-margo pits. This allows conifer tracheids to function effectively in structural support, while attaining per-area xylem conductivities comparable to, or exceeding, those of some angiosperms when the two wood types have equal conduit diameter and length (Jagels and Visscher 2006, Pittermann et al. 2005, Pittermann et al. 2006a, Pittermann et al. 2006b).

Broadly speaking, seed plants have pursued one or the other of these alternative strategies throughout their evolutionary history. Paleobotanists routinely distinguish between the dense pycnoxylic wood characteristic of coniferophytes and wood composed of large conducting and abundant living cells, termed manoxylic, found in many angiosperms and early seed plants (Esau 1977, Stewart and Rothwell 1993). Both manoxylic and pycnoxylic woods have evolved within multiple lineages (Beck et al. 1982, Galtier and Meyer-Berthaud 2006, Namboodiri and Beck 1968). Understanding xylem evolution through time, thus, requires functional comparisons, interpreted in the contexts of stratigraphy and phylogeny. 
We use morphospace analysis to facilitate the functional interpretation of fossil xylem cells. Beginning with seminal work on coiling of nautiloids by Raup (Raup 1966, 1967), morphospaces have been used to characterize morphological variation within and among fossil taxa. Two kinds of morphospaces have predominated: theoretical spaces that take shape from general rules or equations of form, and empirical spaces, which are derived from specimen measurements and have the resulting n-dimensions reduced using data reduction techniques such as singular value decomposition (McGhee 1999). Each approach has its limitations: theoretical morphospaces can be limited by the fidelity with which their initial rules or equations capture processes operating during morphological evolution, and statistically-derived morphospaces lose or gain dimensionality based on the number of initial data points, making them inherently unstable. Furthermore, these morphospaces have, to date, largely focused on describing disparity and inferring parameters such as development and ecology, rather than embedding function directly within the initial dataset. Recent work on multiple origins of leaves in land plants (Boyce and Knoll 2002) has shown that development can be embedded directly within a morphological dataset. We propose to do the same with physiology.

Plants are an ideal set of organisms to test a physiological approach to morphospace analysis. First, basic plant life strategies vary little across the clade. Save for a limited diversity of parasites and saprophytes, all living plants conduct photosynthesis using water and carbon dioxide as substrates, and fossil plants worked the same way. Second, because they are stationary, plants rely on chemical and biophysical means to adapt to their physical and biological environments. Thus, the ability of plants to conduct water and support above-ground tissues relates directly to the structure of 
xylem and other cells in the stem. Finally, because they contain the decay-resistant biopolymer lignin, plant tissues that conduct water and provide physical support have a high potential for preservation in fossils.

We focus on the functional evolution of xylem cells for several reasons. First, they are abundant in the fossil record, with conducting cells preserved in plants as old as the Silurian (Edwards 2003). By definition, all lineages of vascular plants inherited their xylem cells from a common Paleozoic ancestor; morphospace analysis allows us to examine the functional consequences of evolutionary modification of the size, shape, and conductivity of these cells.

Second, wood cells have been a focus of much research in plant biology, and so the quantitative physiological effects of wood anatomy are well-studied (Tyree and Ewers 1991, Zimmermann 1983). Wood structure has a strong influence on plant hydraulics, which, in turn, controls how often stomata open and, thus, indirectly limits the amount of carbon assimilation that can take place in leaves (Buckley 2005, Kramer and Boyer 1995, Taiz and Zeiger 2002).

Finally, there are well-known tradeoffs between structure and function in xylem cells, and well-described and -characterized patterns of hydraulic competition, particularly between angiosperms and conifers.

In this paper, we use a model of water transport through wood cells to construct a three-dimensional morphospace of xylem cells where each axis has a discrete anatomical range, creating a space within which every point is physiologically meaningful. A physiologically explicit morphospace allows us to integrate phylogeny, function, and time in an effort to shed light on questions of xylem evolution. 


\section{Methods}

We adapted a model, developed by Sperry and Hacke (2004, Hacke et al. 2004) for single-cell hydraulics, to calculate resistance through tracheids containing torusmargo or homogeneous pits. We have applied this model to fossil plants in earlier work, and the methods and results are described in detail therein (Wilson et al. 2008).

\section{Model description}

According to the Ohm's Law analogy, water flow through plant vascular systems is analogous to the flow of current through an electrical circuit (Comstock and Sperry 2000, Hacke et al. 2004, Sperry and Hacke 2004, van den Honert 1948). Both are driven by gradients: a vapor pressure gradient between the interior of a leaf and the atmosphere in the case of plant tissues, and a voltage drop across a circuit in electrical circuits. Resistance $\left(\underline{\mathrm{R}}_{\text {tot }}\right)$ is often expressed in terms of conductance $(\underline{\mathrm{K}})$, which is the inverse of total resistance and therefore a measure of flow that is independent of pressure gradient (Equation 1). Conductivity (conductance per unit length) is often normalized to conduit cross-sectional area $\left(\underline{\mathrm{K}}_{\mathrm{sc}}\right.$; units: $\mathrm{m}^{2} / \mathrm{MPa}^{*} \mathrm{~s}$; Equation 2$)$ or wall-specific area $\left(\underline{\mathrm{K}}_{\mathrm{sp}}\right.$; units: $\mathrm{m}^{2} / \mathrm{MPa}^{*} \mathrm{~s}$; Equation 3).

$$
\begin{aligned}
& \underline{\mathrm{K}}=\frac{1}{\underline{\mathrm{R}}_{\text {tot }}} \\
& \underline{\mathrm{K}}_{\mathrm{sc}}=\frac{\underline{\mathrm{L}}_{\text {tracheid }}}{\underline{\mathrm{R}}_{\text {tot }} \underline{\mathrm{A}}_{\text {conduit }}} \\
& \underline{\mathrm{K}}_{\mathrm{sp}}=\frac{\underline{\mathrm{L}}_{\text {tracheid }}}{\underline{\mathrm{R}}_{\text {tot }} \underline{\mathrm{A}}_{\text {wall }}}
\end{aligned}
$$


Total resistance has two components, from the lumen and the end-wall, respectively (Equation 4):

$$
\underline{\mathrm{R}}_{\text {tot }}=\underline{\mathrm{R}}_{\text {lumen }}+\underline{\mathrm{R}}_{\text {wall }}
$$

Flow through the lumen (Equation 4) is described by the Hagen-Poiseuille equation for flow through a cylindrical tube (Lancashire and Ennos 2002). Flow is proportional to the viscosity of water ( $\underline{v}_{\mathrm{H} 2 \mathrm{O}}$; units: ) and one-half the tracheid length, the average distance a parcel of water crosses during its traverse of a tracheid. This value is inversely proportional to the $4^{\text {th }}$ power of the conducting cell's diameter. Thus, a small change in diameter can have a dramatic effect on the lumen resistance:

$$
\underline{\mathrm{R}}_{\text {lumen }}=\frac{64 \underline{\mathrm{v}}_{\mathrm{H}_{2} \mathrm{O}} \underline{\mathrm{L}}_{\text {tracheid }}}{\pi\left(\underline{\mathrm{D}}_{\text {tracheid }}\right)^{4}}
$$

End-wall resistance is a function of the number, size, and porosity of pits. Pits are modeled as resistors in parallel: an increase in the number of pits reduces the resistance of an individual cell (Equation 6). Water enters and leaves cells by flowing through two sets of pits, so the resistance from pits is doubled in the model.

$$
\underline{\mathrm{R}}_{\text {wall }}=2 \frac{\underline{\mathrm{R}}_{\text {pit }}}{\underline{\mathrm{N}}_{\text {pits }}}
$$

Pits have an aperture and a membrane (Equation 7). Pit apertures (Figure 1) have a diameter $\left(\underline{D}_{a p}\right)$ and a thickness $\left(\underline{t}_{a p}\right)$ and are modeled as small cylindrical tubes according to the Hagen-Poiseuille equation (Equation 8). Pit membranes contain pores through which water passes from one cell to another. Membranes are modeled as thin sheets (Vogel 1994) containing a number of pores $\left(\underline{N}_{\text {pore }}\right)$ with a given diameter $\left(\underline{D}_{\text {pore }}\right.$; Equation 9). These pores are often modeled as straight channels, though in SEM 
observation they often appear tortuous and partially occluded by gel-like macromolecular compounds, such as pectin or hemicellulose (Choat et al. 2008, Jansen et al. 2007, Rabaey et al. 2006, Sano and Jansen 2006). As in a previous study (Wilson et al. 2008), we used a resistivity constant ( $\alpha$; unitless) to modify the pit membrane's porosity. The previous study derived $\alpha$ values for homogeneous pit membranes and torus-margo pits, and those values are used here: 16 and 1, respectively.

$$
\begin{gathered}
\underline{R}_{\text {pit }}=\alpha \underline{R}_{\text {membrane }}+2 \underline{R}_{\text {aperture }} \\
\underline{R}_{\text {aperture }}=\frac{128 \underline{\mathrm{t}}_{\text {ap }} \underline{\mathrm{v}}_{\mathrm{H}_{2} \mathrm{O}}}{\pi \underline{\mathrm{D}}_{\text {ap }}{ }^{2}}+\frac{24 \underline{\underline{\mathrm{H}}}_{2} \mathrm{O}}{\underline{\mathrm{D}}_{\text {ap }}{ }^{3}} \\
\underline{\mathrm{R}}_{\text {membrane }}=\frac{24 \underline{\mathrm{v}}_{\mathrm{H}_{2} \mathrm{O}}}{\underline{\mathrm{N}}_{\text {pore }} \underline{\mathrm{D}}_{\text {pore }}{ }^{3}}
\end{gathered}
$$

Examination of these equations shows that the most important factors in determining tracheid-level conductivity are, in decreasing order of importance: tracheid diameter $\left(\mathrm{D}_{\text {tracheid }}\right)$, end-wall resistance $\left(\mathrm{R}_{\text {wall }}=2 * \mathrm{R}_{\mathrm{pit}} / \mathrm{N}_{\text {pits }}\right)$, and tracheid length $(\mathrm{L})$. We use these three terms as axes for our morphospace.

Pit area resistance $\left(\underline{r}_{\mathfrak{p}}\right)$

To normalize for the effect of increased pit area, we calculated pit area resistance $\left(\underline{\mathrm{r}}_{\mathfrak{p}}\right)$ for our taxa by normalizing end-wall resistance to pit membrane area (Equation 10):

$$
\underline{\mathrm{r}}_{\mathrm{p}}=\frac{\underline{\mathrm{R}}_{\text {wall }}}{2}\left(\underline{\mathrm{A}}_{\text {pit }} \frac{\underline{\mathrm{N}}_{\text {pits }}}{2}\right)
$$

We plotted pit area resistances against tracheid dimensions to look in detail at torus-margo pits versus pits with homogeneous pit membranes. Recent work has shown that there are significant differences between these two pit types when pit resistance is 
normalized to area; because of the large pores in the margo, conifers have pit area resistances up to two orders of magnitude lower than those of angiosperms (Pittermann et al. 2005, Pittermann et al. 2006a, Pittermann et al. 2006b). Consequently, there are significant effects of pit membrane pore size on values of $\underline{r}_{p}$. Taxa that contained scalariform pits (Tetracentron, Trochodendron, and Cycadeoidea) were excluded from this analysis, for reasons described below.

Materials and measurements

We measured xylem cell lengths and diameters from fossil stem material using light microscopy in tandem with the publically available image analysis software package ImageJ (found at: http://rsbweb.nih.gov/ij/), and also compiled values reported in the literature (Andrews 1940, Bailey and Tupper 1918, Bannan 1965, Chrysler 1926, Delevoryas 1955, Hacke et al. 2007, Langdon 1920, Rothwell 1975, Ryberg et al. 2007, Scott et al. 1962, Terrazas 1991). Many of these compiled values are species averages for dozens or hundreds of tracheids (Bannan 1965, Chrysler 1926, Scott et al. 1962). Tracheid diameters were measured from cross-sections (interior wall to interior wall). Tracheid length is difficult to measure in fossil material because thin sections provide an essentially two-dimensional view of a three-dimensionally complex structure. This problem is particularly acute for specimens with long tracheids; two Paleozoic plants, Medullosa and Sphenophyllum, contain tracheids that exceed the 3-4 cm length of standard thin sections (Andrews 1940, Cichan 1985, 1986, Cichan and Taylor 1984). Most seed plants, however, have tracheids that are substantially shorter than thin sections, and we measured individual tracheids for which endwalls were clearly visible. Tracheid 
lengths are, thus, the limiting measurement in our dataset, for both living and extinct plants.

For living conifer and Ginkgo biloba material, each data point represents a species average reported by Bannan (1965) and Bailey and Tupper (1918). For Cycadeoidea and Callistophyton, dimensions are averages of several specimens from literature reports (Rothwell 1975, Ryberg et al. 2007). For Ginkgo beckii, dimensions are our measurements $(\mathrm{n}=30)$ made from type material (Scott et al. 1962). For Cordaites $\mathrm{sp}$. and Lyginopteris oldhamium, each point represents an average of ten tracheids from an individual specimen. For Medullosa, each point represents an average of three tracheids from a single specimen.

We calculated pit resistance from anatomical measurements, including torus diameter, margo diameter, pit thickness, and fraction of xylem cell wall occupied by pits. Pit membrane porosity is based on values estimated from direct measurement or inferred from whole-plant measurements (Choat et al. 2003, Choat et al. 2006, Choat et al. 2004). We constrained pit membrane pore size based on recent work showing that the proportion of resistance coming from pits is approximately $65 \%$ of the total hydraulic resistance through a xylem cell (Sperry et al. 2005, Wheeler et al. 2005). We chose pore size and number based on a pore diameter value that would satisfy this relationship. The fraction of cell walls occupied by pits was measured directly from specimens through serial longitudinal section or taken from anatomical descriptions, figures, or other reports in the literature (Greguss 1968, Greguss and Balkay 1972, Pittermann et al. 2006a).

We measured tracheid dimensions and calculated pit resistance and tracheid conductivity for six extinct seed plants, twelve genera of extant gymnosperms, and three 
species of vesselless angiosperms (Table 1, Figure 2). Our fossil seed plants include the Carboniferous stem seed plants Medullosa, Lyginopteris, and Callistophyton; the Paleozoic stem coniferophyte Cordaites; the Mesozoic gymnosperm Cycadeoidea; and a Miocene ginkgophyte, Ginkgo beckii. The twelve genera of extant gymnosperms include three cycads (Cycas, Microcycas, Dioon), Ginkgo, and eight conifers from the families

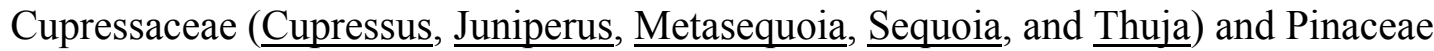
(Picea, Pinus, and Pseudotsuga). For several conifer genera, we obtained values for multiple species (Table 1). We also included measurements from three species of extant vesselless angiosperms in the families Winteraceae and Trochodendraceae: Drimys winteri, Trochodendron araloides, and Tetracentron sinense. All extant genera in our sample set have fossil records that extend into the Mesozoic, making them effective proxies for Mesozoic and Cenozoic torus-margo bearing conifers as well as for vesselless angiosperms. Despite the uncertainties in reconstructing whole-plant ecology and stature from fossils, this dataset contains plants that are arborescent (e.g., Metasequoia, Ginkgo beckii, vesselless angiosperms), shrubs or small in stature (e.g., Cycadeoidea, cycads), climbers or creepers (e.g., Lyginopteris, Callistophyton, Cordaites), or uncertain (e.g., Medullosa).

Nine of our plant genera contain torus-margo pits (both Ginkgo species and eight conifer genera), eight genera contain homogeneous pit membranes (Medullosa, Lyginopteris, $\underline{\text { Callistophyton, Cordaites, }}$ Cycas, Microcycas, Dioon, and Drimys), and three contain scalariform pits (Cycadeoidea, Tetracentron, and Trochodendron). We have previously modeled fluid flow through torus-margo and homogeneous pits (Wilson 
et al. 2008) and have created a method to calculate pit resistance in scalariform pits to simulate fluid flow in the last three taxa.

Scalariform pits

Computation of resistance through scalariform pits has remained a difficult problem. The elliptical shape of scalariform apertures complicates direct analytical solution of the Hagen-Poiseuille equation (Equations 5, 8), and both the presence of bars in some scalariform membranes (Carlquist 2001) and their unknown function have further frustrated efforts to simulate flow through scalariform pits. Others have modeled an analogous anatomical structure, simulating flow from one vessel element to another (Ellerby and Ennos 1998), but the conducting cells in these simulations did not contain pit membrane between their bars. Furthermore, it is unclear if any species of Cycadeoidea contained bars within their pit membranes, although most appear to lack prominent bars.

We measured pit area in Cycadeoidea, Tetracentron, and Trochodendron tracheids and simulated three scenarios to resolve this problem for $\underline{\text { Cycadeoidea. We calculated }}$ tracheid resistance and conductivity if pit membranes are as resistive as conifers $\left(r_{p}=6\right.$ $\left.\mathrm{MPa} * \mathrm{~s} * \mathrm{~m}^{-1}\right)$, vesselless angiosperms $\left(\mathrm{r}_{\mathrm{p}}=16 \mathrm{MPa} * \mathrm{~s} * \mathrm{~m}^{-1}\right)$, and eudicots $\left(\mathrm{r}_{\mathrm{p}}=336\right.$ $\left.\mathrm{MPa} * \mathrm{~s} * \mathrm{~m}^{-1}\right)$. Total end-wall resistance is inverted from Equation 10. Average values for pit area resistance values are taken from the literature (Hacke et al. 2007, Pittermann et al. 2006a, Sperry et al. 2007, Sperry et al. 2005). For Tetracentron and Trochodendron, we used published values of pit area resistances and solved the same equation (Hacke et al. 2007). Because we used pit area resistances to calculate total end- 
wall resistance in Cycadeoidea, Tetracentron, and Trochodendron, we excluded them from our morphometric plot of $r_{p}$ versus diameter and length (Figure 5).

We compared our calculated estimates with empirical values of conductivity in living conifers and relatively narrow and short angiosperm vessels from Hacke et al. (2004) and Sperry et al. (2004). This allows us to compare vessels of the same size as our tracheids directly with our analysis.

\section{Results}

Our results show three primary patterns. First, there is a very long tail to the distribution of tracheid sizes. Mean tracheid diameters are large in Medullosa, Callistophyton, and Lyginopteris, while modern conifer tracheids are small, never exceeding $40 \mu \mathrm{m}$ in diameter. Callistophyton and Medullosa also have the longest tracheids, reaching $10 \mathrm{~mm}$ and more than $20 \mathrm{~mm}$, respectively, and other seed plants have much shorter xylem cells, creating a gap within the seed plant morphospace (Figures 3, 4). Some tracheids from Ginkgo biloba can reach dimensions of Lyginopteris and Callistophyton, but their occurrence is rare (Scott et al. 1962).

Second, most living gymnosperms occupy a small portion of the morphospace, defined by narrow, short tracheids with moderate total pit resistances. Cycads, cyacadeoids, ginkgophytes, and conifers all overlap within this range, which is distinct from that occupied by the stem group seed plants in our sample set (Figure 3). Third, the dimensions and pitting style of Cycadeoidea suggest, though they do not prove, that its xylem may have functioned with pit area resistances similar to those of the living vesselless angiosperms Tetracentron and Trochodendron. Conifers have notably low pit 
area resistances, and large-tracheid-bearing seed plants have high values of $r_{p}$ (Figure 5). This is largely a function of pit membrane pore size and pit area.

When these results are used to calculate single-tracheid conductivities, medullosan tracheids occupy space that also contains short, relatively narrow vessels (Hacke et al. 2006, Sperry and Hacke 2004), while fossil coniferophytes and cycads fall near living conifer tracheids (Figures 6,7). In the Paleozoic, apparently viny seed plants occupied the upper range of conductivity space (Figure 8). Coniferophytes always occupy the lower end-with or without torus-margo pits. Modern angiosperms occupy and exceed the range of conductivity space that was formerly occupied by medullosans and other stem group seed plants.

No living seed plant group occupies the space that Medullosa, Callistophyton, and Lyginopteris held, with wide, long, and low-resistance tracheids. Today, the only plant that may fit in this space is the Costa Rican climbing fern Salpichlaena volubilis, reported to have tracheid diameters in excess of $200 \mu \mathrm{m}$ and lengths in excess of $20 \mathrm{~mm}$ (Veres 1990). It is probable that this area of morphospace is limited to tropical, large-leaved, tracheid-bearing plants that do not rely on conducting cells for structural support (DiMichele et al. 2006, Mosbrugger 1990, Wilson et al. 2008, Wnuk and Pfefferkorn 1984).

Taphonomy obscures individual pit membrane porosity in most pre-Cenozoic fossil plants, with only rare exceptions (Beck and Wight 1988), forcing us to rely on comparative biology for estimates of pore diameter. While we can differentiate torusmargo pits from circular bordered pits in fossil plants, we may never know exactly how large pores were in the pit membranes of ancient seed plants. As in other experimental 
and theoretical work, pit membrane porosity represents the largest uncertainty in this analysis (Choat et al. 2003, Choat et al. 2008, Wilson et al. 2008). Our estimates of conductivity fall within the ranges of measurements from living conifers and angiosperms, however, adding confidence to our simulations (Figure 6).

Low-resistance transport evolved at least once early in the seed plant clade. Stem seed plants, particularly ones found within the tropical Euramerican coal swamps, achieved low-resistance transport by increasing both single-tracheid dimensions and pit area.

\section{Discussion}

Interpretation of wood evolution requires that information from our morphospace analysis be integrated with phylogenetic and stratigraphic data. Molecular phylogenies suggest that angiosperms are sister to all other living seed plants. Most major seed plant clades are extinct, however, and phylogenetic analyses of the full range of seed plant diversity remain a challenge. For the purposes of discussion, we illustrate a tree modified from Doyle (2008; Fig. 2), but note that our conclusions about xylem evolution do not depend strongly on choice of phylogeny.

The evolution of pycnoxylic wood

Pycnoxylic wood occurs in a number of Paleozoic plants, including the promgymnosperm Archaeopteris (Beck 1960, 1962, 1970, Beck and Wight 1988), $\underline{\text { Cordaites, }}$, conifers, Glossopteris (Maheshwari 1972), and, perhaps, a greater diversity of 
clades recorded by form taxa such as Dadoxylon (Erasmus 1976, Scott 1902) and Zalesskioxylon (Feng et al. 2008).

At a minimum, pycnoxylic wood evolved independently in the progymnosperms; in the common ancestor of ginkgophytes, cordaites, and conifers [as the earliest known seed plants have manoyxlic wood much like that of aneurophyte progymnosperms (Galtier 1988, Galtier and Meyer-Berthaud 2006, Serbet and Rothwell 1992)]; and in the clade repsented by glossopterids. The torus-margo pitting of extant conifers and Ginkgo evolved twice, independently in each of these clades. Such a conclusion is supported by phylogenies (Crane 1985) in which the plesiomorphic character of ginkgophyte reproductive biology places it below a node containing the reproductively similar cordaites and conifers (Florin 1950, 1951, Rothwell 1982, Rothwell et al. 1997). Regardless of this relationship, however, the independent origin of torus-margo pitting in Ginkgo is mandated by the observation that all known Paleozoic conifers have bordered pits with simple pit membranes (Rothwell 1982, Rothwell et al. 1997, Stewart and Rothwell 1993, Taylor and Taylor 1993). The earliest known pycnoxylic wood with torus-margo pits occurs in the Hettangian (Early Jurassic, $210 \mathrm{Ma}$; M. Philippe, pers. comm.). Insofar as stem ginkgophytes are well-known from the Permian and Triassic (Anderson et al. 1998, Florin 1949), neither stem conifers nor stem ginkgophytes had torus-margo pits.

Torus-margo pits have also been reported from the Gnetales, in Ephedra and Gnetum (Carlquist 1996). Because of their uncertain phylogenetic placement (Bateman et al. 2006, Burleigh and Mathews 2004, Doyle 2006, Doyle 2008), a confirmed appearance of torus-margo pits in this group could represent either retention of the 
plesiomorphic state from crown group conifers, or another independent origin in addition to Ginkgo.

All conifers and other seed plants with pycnoxylic wood and simple pit membranes are extinct; all extant seed plants with pycnoxylic wood have torus-margo pits. This strongly suggests that the torus-margo pit conferred selective advantage on its bearers, although we cannot rule out selection for other traits that co-occurred with these modified pit membranes. Our morphospace suggests that the selective advantage was not simply higher conductivity, as Paleozoic plants with conifer-like wood achieved conductivity similar to that of living conifers by increasing the total area of pitting on tracheid walls. More likely, advantage must be sought in the dual function of pycnoxylic tracheids. Because they allow comparable rates of water transport with fewer pits, torusand-margo tracheids are mechanically stronger than those of pycnoxylic Paleozoic woods. The torus-margo structure also allows for a tighter seal against embolism, if such events are rare; when subject to repeated embolism events, the torus may become stuck against the aperture, permanently sealing the tracheid against fluid flow (Hacke et al. 2001b, Pittermann et al. 2005, Pittermann et al. 2006a, Pittermann et al. 2006b, Sperry et al. 1994, Sperry and Tyree 1990, Zimmermann 1983). Perhaps the tracheids observed today in conifers and Ginkgo present the optimum balance among mechanical support, cavitation avoidance, and water conductivity in plants developmentally committed to pycnoxylic wood.

Consequences of high-conductivity, tracheid-based xylem 
High conductivity xylem based on tracheids can only function at a physiological cost. The same features that allow medullosan or callistophytalean tracheids to move large volumes of water with low resistance also make them vulnerable to damage from drought and frost: wide, long, and highly pitted tracheids are extremely vulnerable to cavitation and embolism, whereas narrower, shorter, and less densely pitted tracheids are relatively risk averse (Dixon 1909, 1914, Hacke et al. 2001a, Sperry and Ikeda 1997, Sperry et al. 1994, Sperry and Tyree 1988, 1990, Tyree and Ewers 1991, Tyree et al. 1999, Tyree and Sperry 1988, 1989). Furthermore, the structure of medullosan xylem in particular, with extremely long tracheids anastomosing in a network, allows embolism to propagate over long distances within a stem (Loepfe et al. 2007). The high proportion of living cells in the xylem of manoxylic plants may reflect the physiological need to refill embolized tracheids (Wilson et al. 2008).

The large-tracheid-based hydraulic structure also commits plants to environments without freeing or moisture stress. During freezing, air is pushed out of solution; larger cells will produce more air when frozen, leading to larger cavitation events. A large literature shows that large conduits are more vulnerable to cavitation than small conduits (Ball et al. 2006, Ball et al. 2002, Davis et al. 1999, Hammel 1967, Sperry and Sullivan 1992, Sucoff 1969). Ice has an extremely low water potential and creates a hydraulic gradient that can dehydrate nearby cells and damage cell membranes (Pearce 2001, Steponkus 1984). Large tracheids, like vessels, are potential sources of nucleation, especially if their diameter exceeds 44 microns (Davis et al. 1999). Modern plants mitigate this stress by refilling cavitated tracheids through root pressure or another, more cryptic, mechanism to generate positive pressure in the xylem, or they grow new wood 
every year. The small amount of wood found in the Paleozoic seed plants with large tracheids rules out new wood formation, and the lack of hydathodes on their leaves argues against root pressure. In the absence of a mechanism to repair freeze-thaw cavitation, it is unlikely that plants with large tracheids could survive a cold climate. It is telling that the most conspicuous group of angiosperms that have reverted to tracheidbased transport, the Winteraceae, appear to have changed in response to increased exposure to frost events (Feild et al. 2002, Feild et al. 2000).

As noted above, moisture stress imparts similar size constraints to water transport tissues but for different reasons: large tracheids have more pit area and are vulnerable to defects in pit membrane development, leading to rare large pores that can allow embolism to spread (Wheeler et al. 2005). Finally, the thickness-to-span ratio of

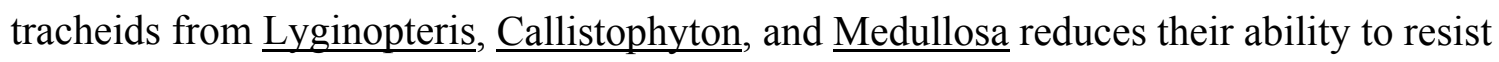
drought-induced embolism and implosion (Hacke and Sperry 2001, Hacke et al. 2001a, Hacke et al. 2001b). Although these cells' reduced ability to resist strong tensions does not directly correspond with a reduced degree of structural support, given the complex nature of biomechanical support in vascular plants (Carlquist 2001, Cichan 1986, DiMichele 1979, DiMichele and DeMaris 1987, DiMichele and Gastaldo 2008, Niklas 1992, Niklas and Spatz 2004, Rowe and Speck 2004, Rowe et al. 1993), a stem composed of highly conductive, wide tracheids would not, by itself, contribute significant structural support to a plant.

\section{Arborescence and conductivity.-}


In light of a possible tradeoff between low stature and high conductivity, a key component of vegetative success in angiopserms may lie in the vascular cambium, not strictly in high-throughput vessels, as other authors have suggested (Bond 1989). Angiosperm vegetative success may reflect the evolution of a vascular system that can conduct water at high volumes and simultaneously retain the ability to grow tall. In this scenario, the key innovation is the invention of fiber-based structural support derived from the vascular cambium. The Paleozoic plants that occupied the portion of our morphospace that is now angiosperm-dominated were likely scrambling or climbing plants, rather than free-standing trees, limiting the ecological zones they could occupy. Angiosperms are not limited in this manner and can achieve stature comparable to conifers and Ginkgo, but with high-conductivity wood irrigating large leaf areas. This capacity for structural evolution relies on a vascular cambium that can initalize both vessels and fibers, and fibers are the compoenent unexplored by other clades. A recent analysis of Early Cretaceous European wood supports this interpretation: earliest angiosperm wood contained relatively thin-walled fibers, leading to a low-diversity flora composed of rapidly-growing, scrambling forms; the evolution of thick-walled fibers allowed for stiff woods and accompanied the radiation of angiosperms into many different environments (Philippe et al. 2008).

There have been further elaborations on this form within the angiosperms: palms achieve large stature without a vascular cambium by means of their primary thickening meristem (Tomlinson 1990); many species of the dicot Gunnera support several meterscale leaves on stems less than a meter high because of structural support conferred by leaf bases (Batham 1943, Wilkinson 2000). The diversity of structural adaptations found 
within plants that contain vessels and fibers far exceeds that in plants with pycnoxylic wood (Mosbrugger 1990, Niklas 1997).

In contrast, once the vascular cambium begins to produce pycnoxylic wood without living cells in association with each tracheid, it may become difficult to revert to a condition in which cambial initials can expand to the diameters and lengths required to make tracheids of medullosan scale. The limited number of living cells prevents tracheids from increasing their initial diameter and length by the factor of 10 needed to reach this size. It is possible that pycnoxylic wood prohibits modes of life that were common among stem seed plants in the Paleozoic, because it is difficult to supply leaves with the amount of water required to irrigate the lamina while maintaining small-diameter stems required to climb or scramble. A vine with coniferophyte tracheids would require a larger area of xylem to support a given flow volume than one that had medullosan tracheids or vessels. Ferns, the most common tracheid-bearing climbing plants in the modern flora, tend to rely on fewer, larger xylem cells to conduct water, rather than large cylinders of xylem (Veres 1990). If plants with pycnoxylic wood were to evolve a condition analogous to the vessel-fiber strategy, perhaps with large tracheids for transport embedded within small cells for support, it is possible that their hydraulic conductivity might be insufficient relative to the efficiency of angiosperm wood. This difference would be accentuated if pycnoxylic tissue lacked torus-margo pitting.

Given these differences in structural support and conductivity, it is somewhat surprising that coniferous and angiosperm forests are almost equally abundant: large, relatively low-diversity gymnosperm forests cover the boreal regions of the Northern Hemisphere, and high-diversity angiosperm forests dominate the equatorial and 
temperate regions. The functional flexibility conferred on angiosperms by a wide range of anatomical characters, including their vascular cambium, allows them to dominate a wide array of environments, from tropical forests to deserts. Conifers and gymnosperms do not exhibit this range of environmental tolerance, but their dominance of Siberian and Canadian circumpolar forests illustrates their ecological success.

\section{Gigantopterids.-}

The Permian gigantopterids, largely found as compression fossils in China and the central United States, are well-known for their angiosperm-like vegetative organs, including large, entire-margined leaves and putative vessel elements (Beck and Labandeira 1998, Glasspool et al. 2004a, Glasspool et al. 2004b, Li and Taylor 1998, Li et al. 1996, Mamay et al. 1988). Although permineralized specimens are rare, and reproductive organs have never been found - preventing any taxonomic link with other seed plant groups — gigantopterid vegetative features suggest that they may resemble medullosans and angiosperms in functional space, rather than conifers. Gigantopterid xylem cells, including their putative vessel elements, are remarkably wide $(>300 \mu \mathrm{m})$ and have radial walls that are covered by circular-bordered pits, much like the xylem cells of Medullosa (Li and Taylor 1998, Li et al. 1996). All of these features suggest a plant that lived in a tropical everwet environment and was extremely vulnerable to cavitation, again, much like Medullosa (Wilson et al. 2008).

\section{Environmental context.-}


It is informative to view the Late Paleozoic seed plants with high-conductivity xylem in their environmental context. All of these plant fossils, from Lyginopteris to Gigantopteris, were preserved in swamps, and it is likely that these plants inhabited swampy, everwet environments. During the assembly of Pangaea, which began in the Pennsylvanian and continued through the Permian, these basins were closed, these environments were lost, and these plant groups disappear from the record. Because the taphonomic window is closed, we cannot rule out the possibility that these plants moved to extrabasinal environments, but their absence from the palynological record points toward extinction, rather than migration (Taylor et al. 2008).

Patterns of reducing hydraulic resistance

At the broadest scale, then, it appears that there are two major ways to reduce resistance in xylem cells, by modifying the wall resistance and/or by modifying the lumen resistance (Figure 8).

One way to decrease wall resistance is by increasing the porosity of individual pit membranes. Torus-margo pits allow individual pores to be up to $1 \mu \mathrm{m}$ in diameter (Choat et al. 2008, Lancashire and Ennos 2002, Pittermann et al. 2005, Pittermann et al. 2006a, Sperry et al. 2006). These large pores dramatically increase the porosity of an individual conifer or Ginkgo tracheid, making them competitive with angiosperms (Pittermann et al. 2005, Pittermann et al. 2006a, Zimmermann 1983). The combination of pycnoxylic wood and torus-margo pits allows for low-resistance fluid flow and structural support in the same tissues. 
Another way to decrease tracheid wall resistance is by increasing pit area in the cell. Increasing pit area, either by adding more pits or by enlarging individual pit membranes, will reduce the resistance from xylem cell walls. Tracheids with more or larger pits are rare in living plants but widespread in extinct groups, including $\underline{\text { Lyginopteris, Medullosa, }}$ Callistophyton, Cordaites, early conifers (Philippe and Bamford 2008), tgigantopterids (Li and Taylor 1998), and the Mesozoic seed plant Pentoxylon (Taylor and Taylor 1993). The drawbacks to increased pit area may have included decreased structural support from thinner cell walls (Hacke et al. 2001a, Pittermann et al. $2006 \mathrm{~b}$ ) and an increased probability that embolisms would spread because of microfibril failure, leaving large pores in pit membranes (Choat et al. 2003, Hacke et al. 2007).

The other major way to decrease hydraulic resistance is to minimize the component associated with conducting cell lumens. There are at least two ways to accomplish this: increasing individual cell dimensions or combining individual cells into multicellular vessels.

If all else is held equal (e.g., length-to-diameter ratio, proportion of wall that contains pits), above 30 microns in diameter, the proportion of total resistance coming from lumens is approximately $1 / 3$ of total resistance and decreases with further increases in diameter (Hacke et al. 2004, Schulte et al. 1987, Sperry and Hacke 2004, Sperry et al. 2005, Wheeler et al. 2005). However, larger tracheids provide larger flow rates, and a single tracheid with diameter $r$ will conduct 8 times more water per unit pressure gradient than two tracheids with diameter half the size (Sperry et al. 2005, Tyree and Ewers 1991, van den Honert 1948). Increasing length is effective if fusiform initials are narrow or cannot be enlarged, but length increases do not take advantage of the Hagen-Poiseuille 
relationship and instead increase flow rate in a linear relationship (Comstock and Sperry 2000). Therefore, it is more economical to increase the diameter of the conducting cell, even if it comes at the expense of the number of conducting cells in a stem's crosssectional area.

Relying on a smaller number of large-diameter tracheids appears to be common among stem seed plants, including Lyginopteris, Medullosa, and Callistophyton and is rarely found among living ferns, including Ophioglossum and Salpichlaena volubilis. It is notable that Ginkgo biloba contains broad leaves in addition to a small number of large tracheids, while most conifers lack both (Scott et al. 1962).

Another way to decrease lumen resistance is by linking xylem cells together by dissolving their end walls to create vessels, dramatically increasing the length of the flow path. Combining this with multiple types of tissues derived from the vascular cambium, such as small, thick-walled fibers for structural support, permits the development of wide xylem cells that maximize conductivity. The combination of vessels and fibers is characteristic of the vast majority of angiosperms, some members of the Gnetales (Carlquist 1996), and the Late Paleozoic gigantopterids (Li and Taylor 1998). It is telling that the only genus of living gymnosperms that contains vines, Gnetum, contains vessels mixed with narrow tracheids (Carlquist 1996, Feild and Balun 2008).

\section{Conclusions}

Because their physiological performance is closely tied to preservable anatomical structure, fossil vascular plants are amenable to morphometric analysis that tracks functional diversity through time. Tracheids in most living and extinct gymnosperms are 
functionally similar, but the conducting cells of some stem group seed plants are exceptional: the wide, long, and relatively low-resistance tracheids of Medullosa, $\underline{\text { Lyginopteris, }}$, and Callistophyton conducted water at resistances comparable to those of moderately-sized angiosperm vessels.

Seed plants have used several different physiological strategies to achieve highconductivity xylem, but only two are pursued today: high-porosity torus-margo pits and multicellular vessels. Functional canalization into these two strategies reflects the extinction of non-angiosperm seed plants. Anatomically distinct plants capable of high throughput conduction were common in tropical everwet forests of the Late Paleozoic but did not survive Permian climatic change.

Our analysis highlights two points that become clear only when morphometric and phylogenetic data are combined. First, most previous studies have suggested that the widespread distribution of torus-margo pits is due to the increased fluid flow facilitated by large pores within the membrane; however, our analysis shows that stem coniferophytes had tracheids with comparable fluid flow ability, but reduced structural support and cavitation resistance. It is likely that the evolution of torus-margo pits reflects a balance among fluid flow, safety, and support, rather than simply increased fluid flow.

Also, our analysis suggests that the vegetative success of angiosperms is not simply a function of high-throughput vessels, because some Paleozoic seed plants, including Medullosa, had comparably functioning xylem cells. The key innovation may have been a vascular cambium that permitted development of thick-walled fibers for 
Wilson - 28

structural support, as well as vessels, facilitating the evolution of tall trees containing low-resistance xylem able to irrigate large leaf areas.

\section{Acknowledgements}

We thank N. Michele Holbrook, Fulton Rockwell, and Suzanne Costanza for helpful discussion, and two anonymous reviewers for comments that improved this manuscript. J.P.W. is supported in part by the NASA Astrobiology Institute. 


\section{Figure List}

Figure 1. Model of water transport through xylem cells with morphospace dimensions highlighted: tracheid diameter $\left(\mathrm{D}_{\text {tracheid }}\right)$, tracheid length $\left(\mathrm{L}_{\text {tracheid }}\right)$, and end-wall resistance $\left(R_{w a l l}\right)$. Water enters a cell through a series of apertures on the wall, called pits, flows through the lumen of the cell, and exits through another set of pits. Pit morphology, size, number, and porosity determine total end-wall resistance. Homogeneous pits are characteristic of angiosperms and stem seed plants, and torus-margo pits are found in conifers and Ginkgo. Modified from Choat et al. (2008).

Figure 2. A phylogenetic tree of taxa used in this study, based on Crane (1985), Doyle (2006), and Judd (2007). Extinct lineages are in dark grey, living plants are in light grey. Relationships among fossil taxa are uncertain, but are not critical to the conclusions of this study.

Figure 3. A three-dimensional view of our physiologically explicit morphospace. Axes are tracheid diameter (in $\mu \mathrm{m}$ ), tracheid length (in $\mathrm{mm}$ ), and total end-wall resistance (in $\left.\mathrm{MPa} * \mathrm{~s} * \mathrm{~m}^{\wedge}-3\right)$. Stem seed plants are dark, $\underline{\text { Cordaites }}$ is pink, living conifers are red, cycads are pink triangles, Ginkgo is green, vesselless angiosperms are cyan, and Cycadeoidea is black.

Figure 4. Separate two-dimensional views of our morphospace, split into total end-wall resistance versus diameter and total end-wall resistance versus length. Note the long tail in tracheid diameters that is absent in tracheid lengths. 
Figure 5. Separate two-dimensional views of pit area resistance $\left(r_{p}\right)$ versus length and $r_{p}$ versus diameter. Note that Medullosa and Cordaites have relatively high pit area resistance values, whereas living conifers have low pit area resistance values.

Figure 6. Specific conductivity (conductance normalized to length and wall area: Equation 3) versus length and diameter. Angiosperm and tracheid values are from Hacke et al. (2004) and Sperry et al. (2004).

Figure 7. A histogram of conductivity in Paleozoic seed plants versus extant gymnosperms. Coniferophytes fall near the left wall of both histograms. In the

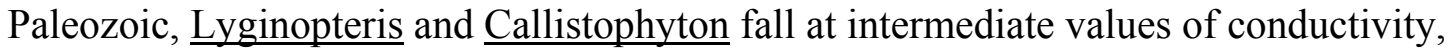
and Medullosa at the high end. In the lower plot, angiosperm vessels fall at high conductivity values and normally exceed values shown here. Medullosa overlaps with small angiosperm vessels.

Figure 8. A decision tree of how to decrease total xylem resistance. There are two ways to decrease resistance: by reducing resistance of the wall and/or the lumen. To reduce end-wall resistance, there are two methods: increasing individual porosity, through the development of the torus-margo pit, or by adding pit area, which appears to be common in Paleozoic seed plants. To reduce lumen resistance, plants have either turned to multicellularity, which is found in angiosperm vessels, or enlarging individual xylem cells, which is found in Medullosa and certain other Paleozoic seed plants. 
Table 1: Taxa measured and values used for this analysis: taxa; diameter; length; pit type; pit density; membrane pore diameter; references. 


\section{Figure List}

Figure 1. Model of water transport through xylem cells with morphospace dimensions highlighted: tracheid diameter $\left(\mathrm{D}_{\text {tracheid }}\right)$, tracheid length ( $\left.\mathrm{L}_{\text {tracheid }}\right)$, and end-wall resistance $\left(\mathrm{R}_{\text {wall }}\right)$. Water enters a cell through a series of apertures on the wall, called pits, flows through the lumen of the cell, and exits through another set of pits. Pit morphology, size, number, and porosity determine total end-wall resistance. Homogeneous pits are characteristic of angiosperms and stem seed plants, and torus-margo pits are found in conifers and Ginkgo. Modified from Choat et al. (2008).

\section{Tracheids:}

Length: $0.1-1 \mathrm{~cm}$

Diameter: 5-80 $\mu \mathrm{m}$

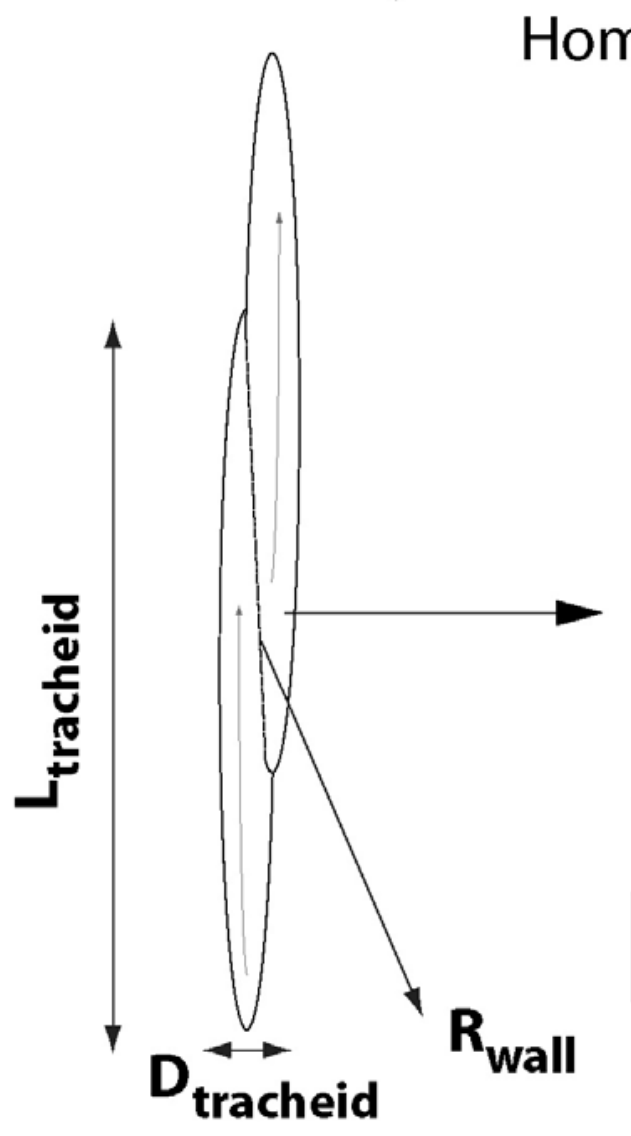

Torus-margo pits pits

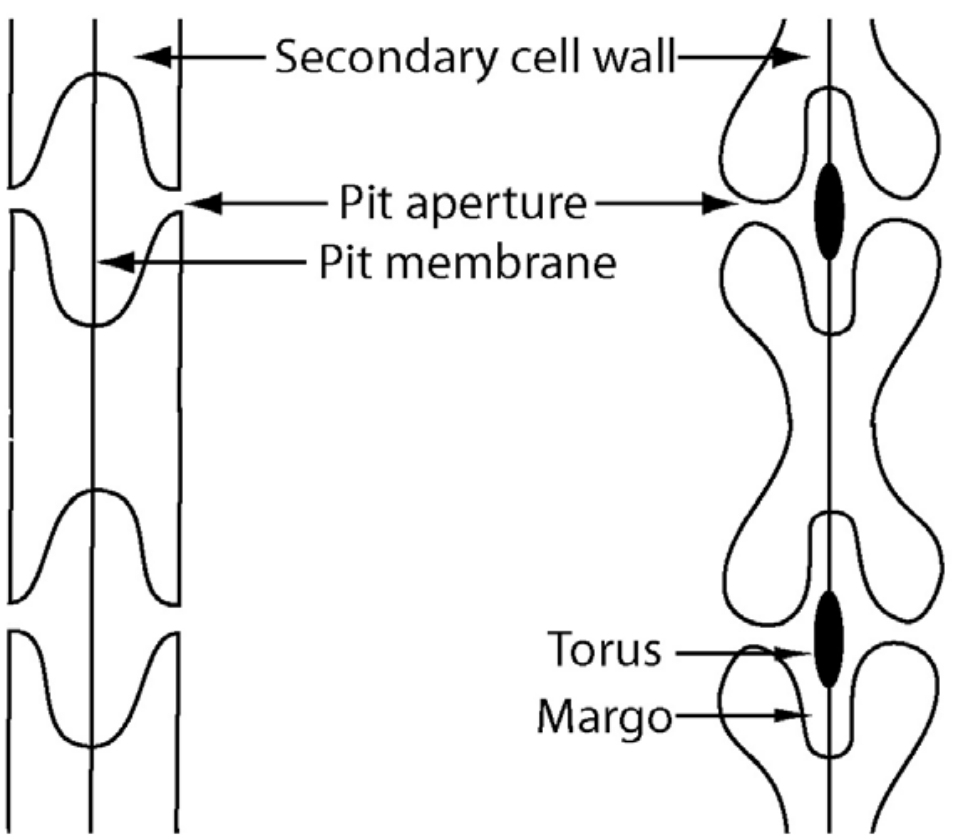


Figure 2. A phylogenetic tree of taxa used in this study, based on Crane (1985), Doyle (2006), and Judd (2007). Extinct lineages are in dark grey, living plants are in light grey. Relationships among fossil taxa are uncertain, but are not critical to the conclusions of this study.

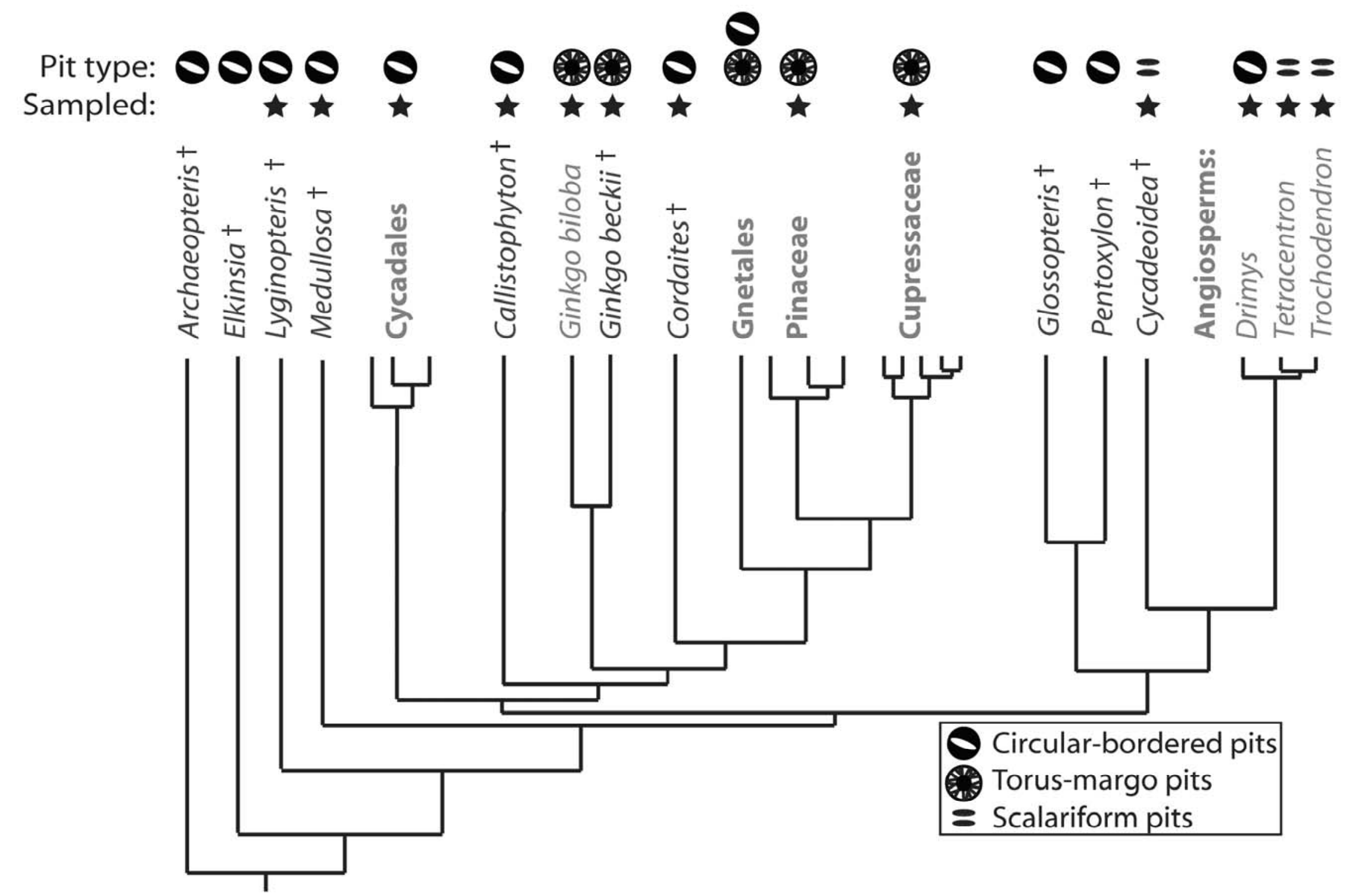


Figure 3. A three-dimensional view of our physiologically explicit morphospace. Axes are tracheid diameter (in $\mu \mathrm{m}$ ), tracheid length (in $\mathrm{mm}$ ), and total end-wall resistance (in $\mathrm{MPa} * \mathrm{~s} * \mathrm{~m}^{\wedge}-3$ ). Stem seed plants are blue, Cordaites is pink, living conifers are red, cycads are pink triangles, Ginkgo is green, vesselless angiosperms are cyan, and Cycadeoidea is black.

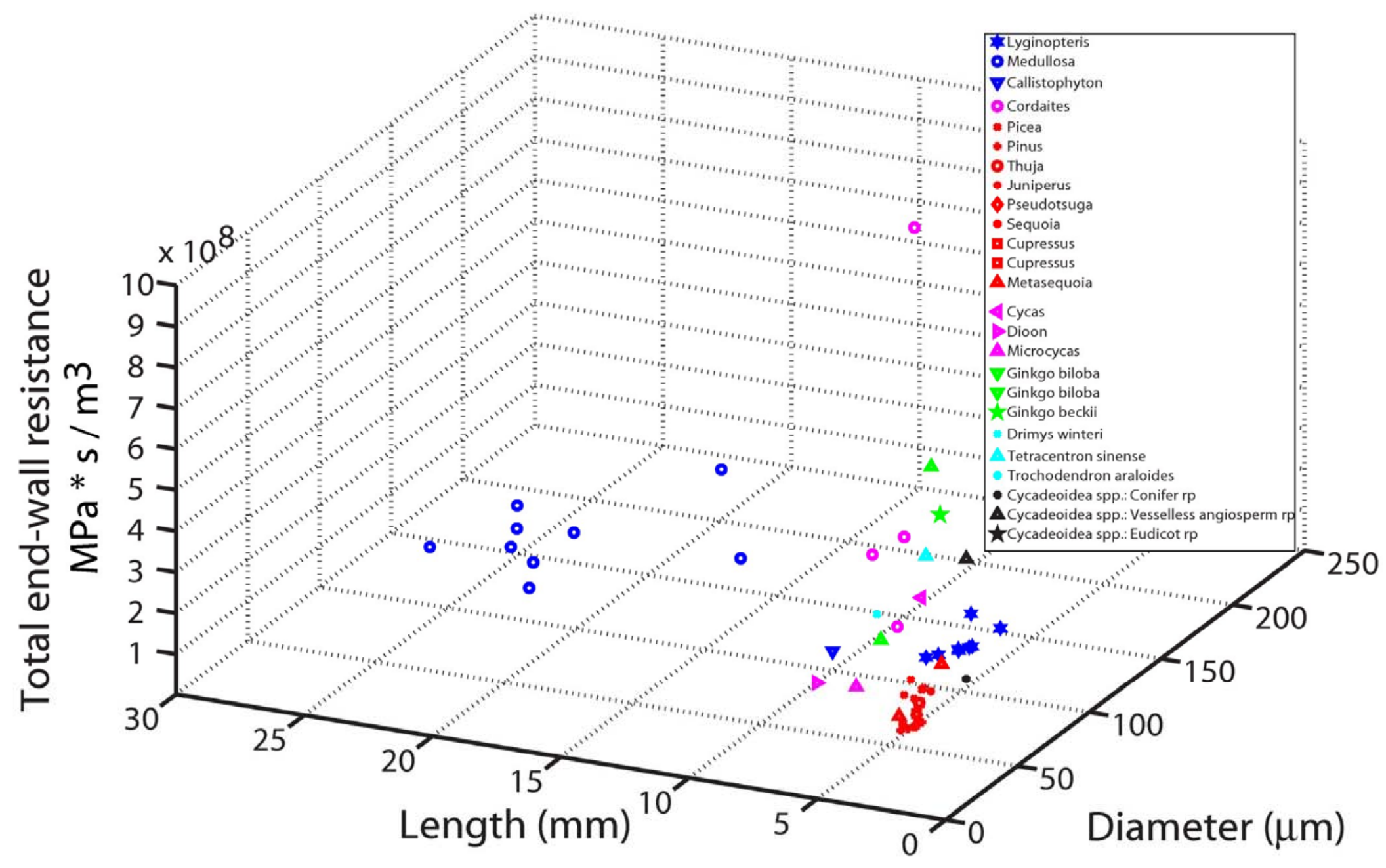


Figure 4. Separate two-dimensional views of our morphospace, split into total end-wall resistance versus diameter and total end-wall resistance versus length. Note the large gap between the longest and average-length tracheids that is absent in tracheid diameters.
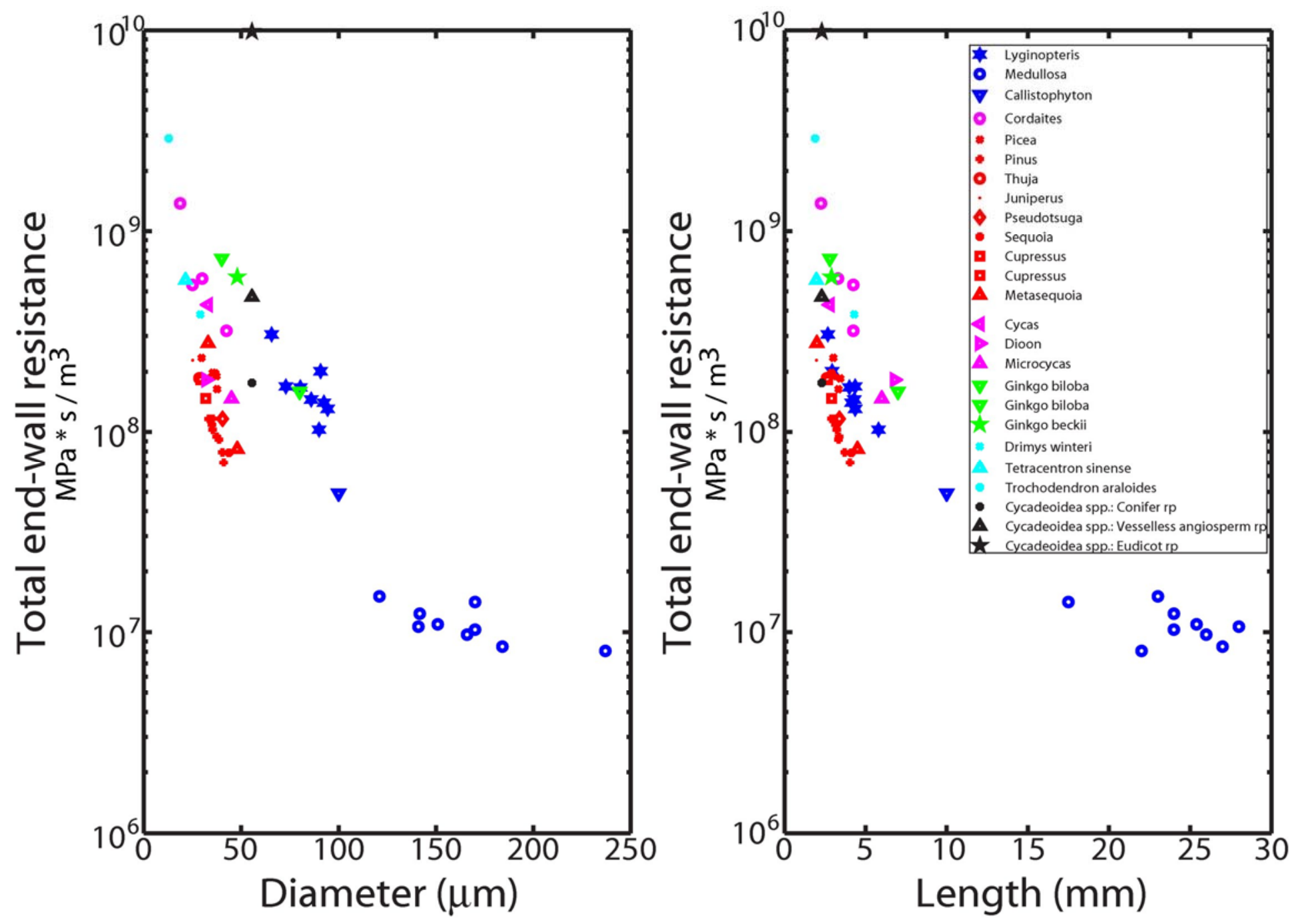
Figure 5. Separate two-dimensional views of pit area resistance $\left(r_{p}\right)$ versus length and $r_{p}$ versus diameter. Note that Medullosa and Cordaites have relatively high pit area resistance values, whereas living conifers have low pit area resistance values.
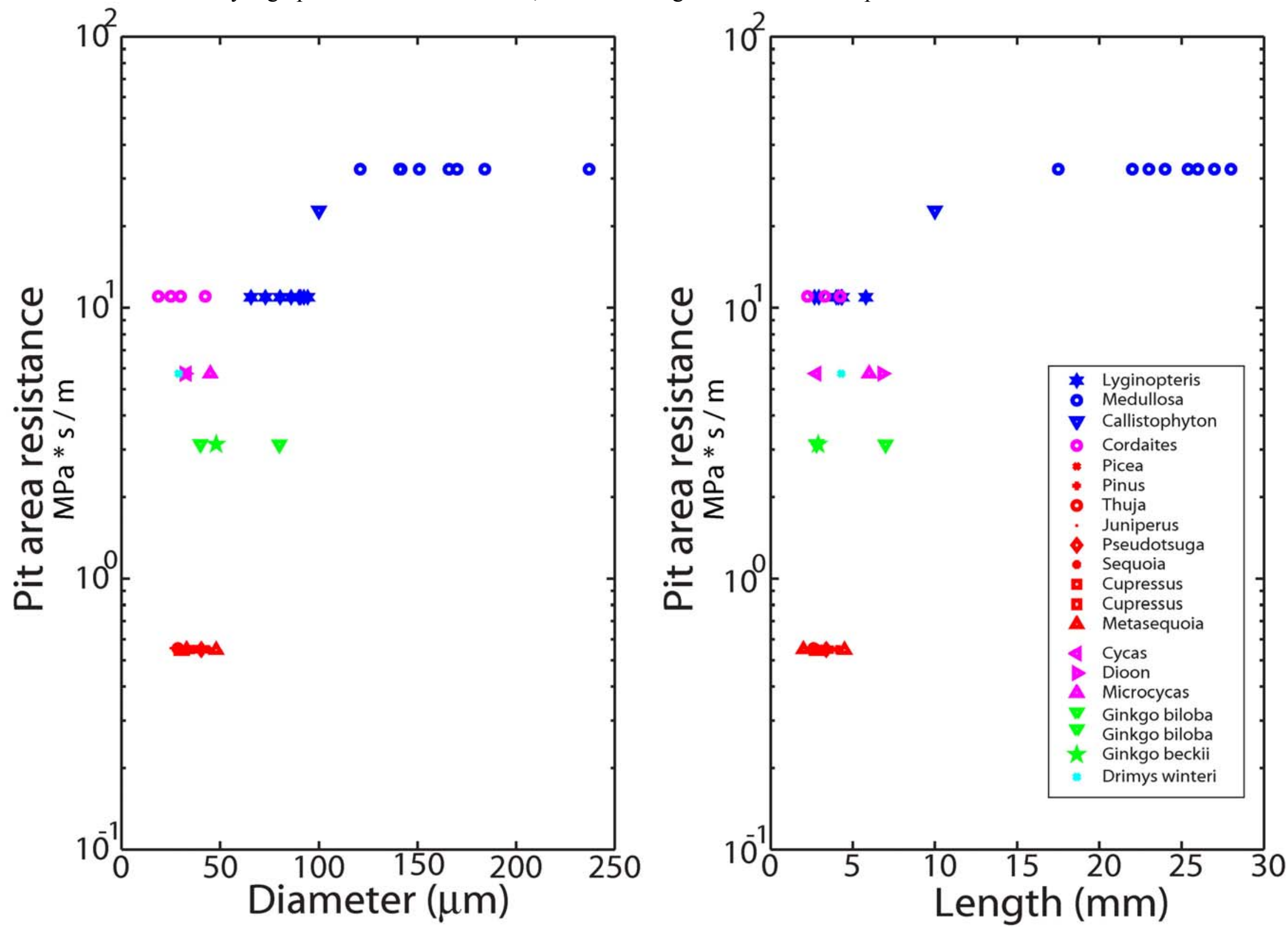
Figure 6. Specific conductivity (conductance normalized to length and wall area: Equation 3) versus length and diameter. Angiosperm and tracheid values are from Hacke et al. (2004) and Sperry et al. (2004).

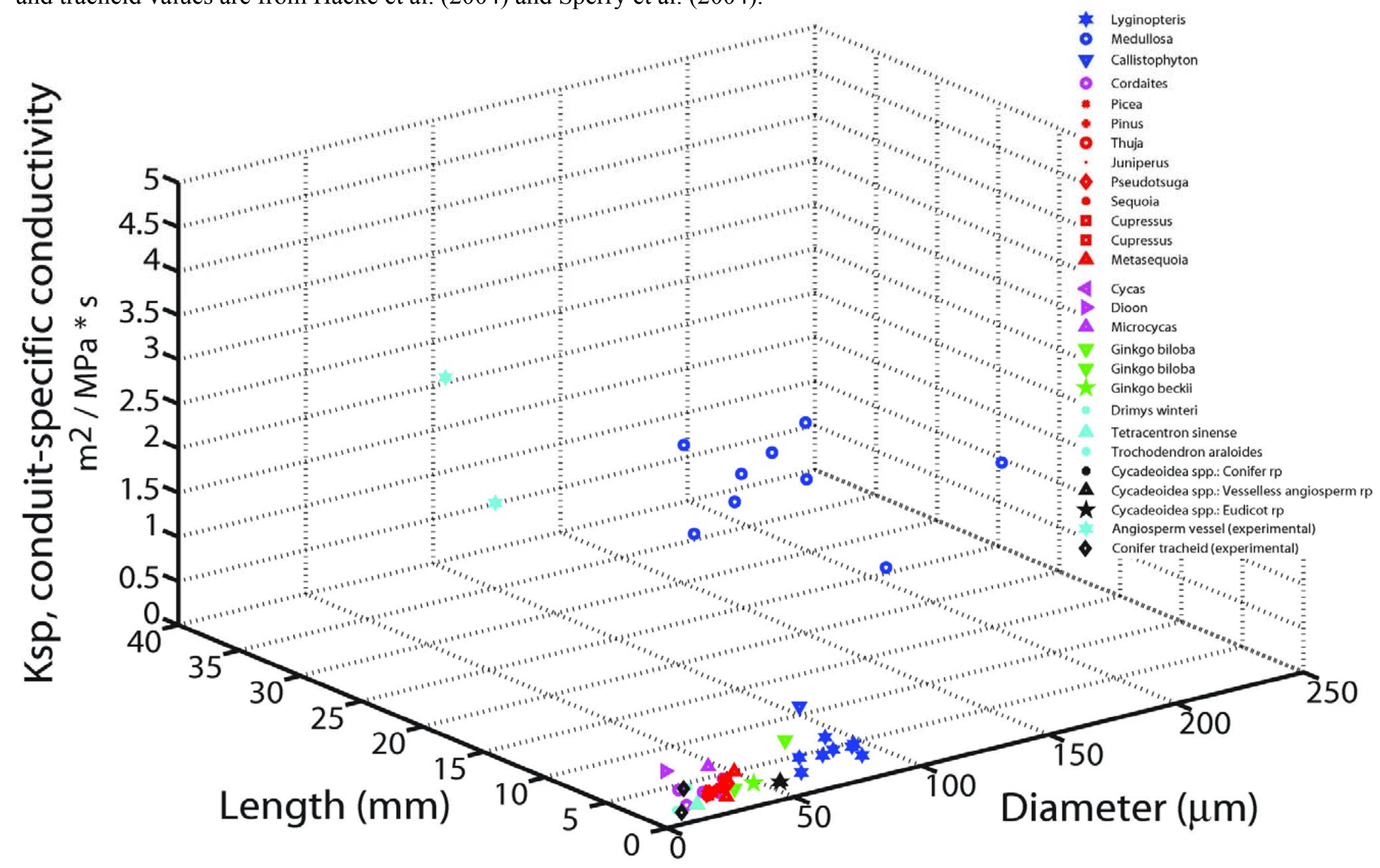


Figure 7. A histogram of conductivity in Paleozoic seed plants versus extant gymnosperms. Coniferophytes fall near the left wall of both histograms. In the Paleozoic, Lyginopteris and Callistophyton fall at intermediate values of conductivity, and Medullosa at the high end. In the lower plot, angiosperm vessels fall at high conductivity values and normally exceed values shown here. Medullosa overlaps with small angiosperm vessels.
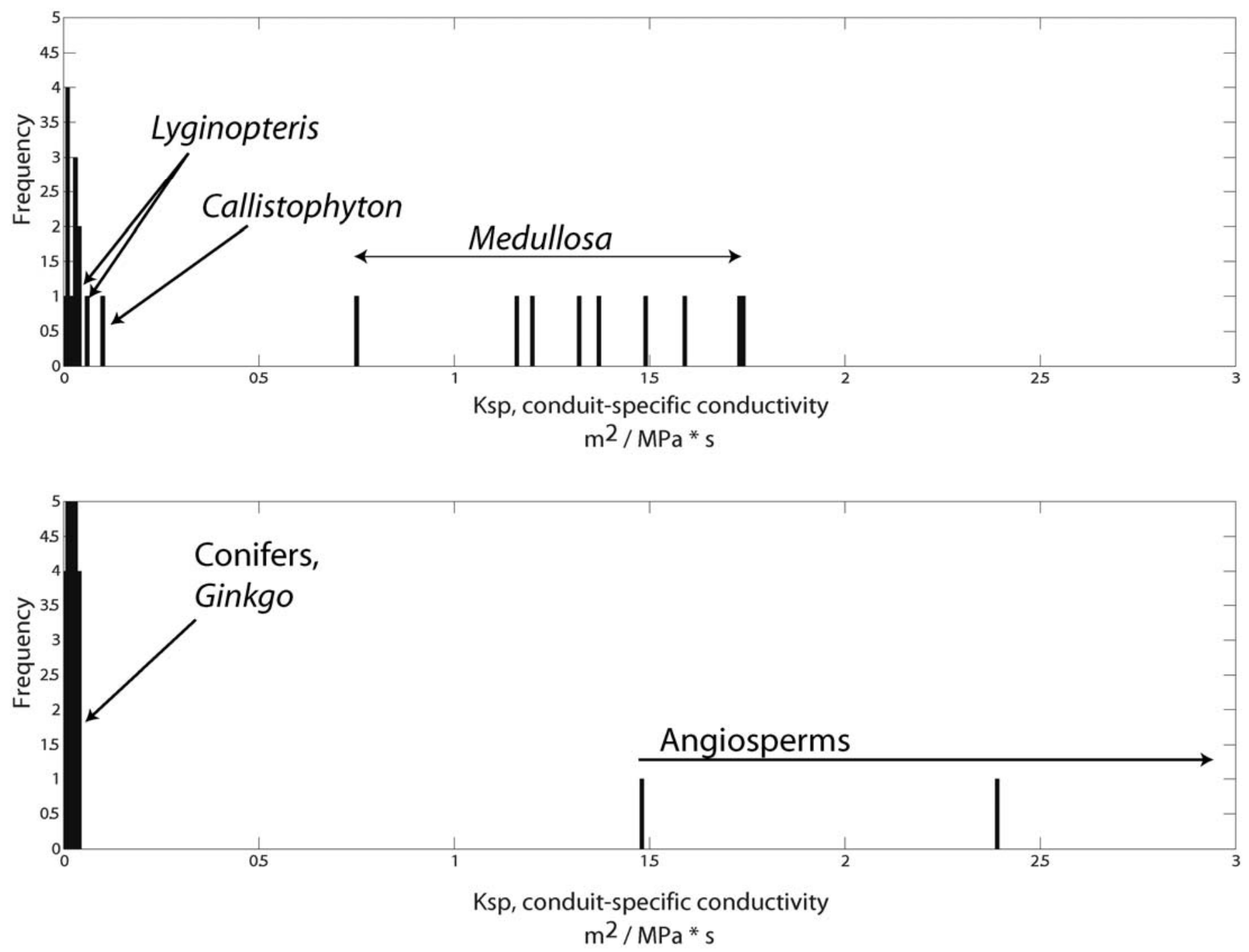
Figure 8. A decision tree of how to decrease total xylem resistance. There are two ways to decrease resistance: by reducing resistance of the wall and/or the lumen. To reduce end-wall resistance, there are two methods: increasing individual porosity, through the development of the torus-margo pit, or by adding pit area, which appears to be common in Paleozoic seed plants. To reduce lumen resistance, plants have either turned to multicellularity, which is found in angiosperm vessels, or enlarging individual xylem cells, which is found in Medullosa and certain other Paleozoic seed plants.

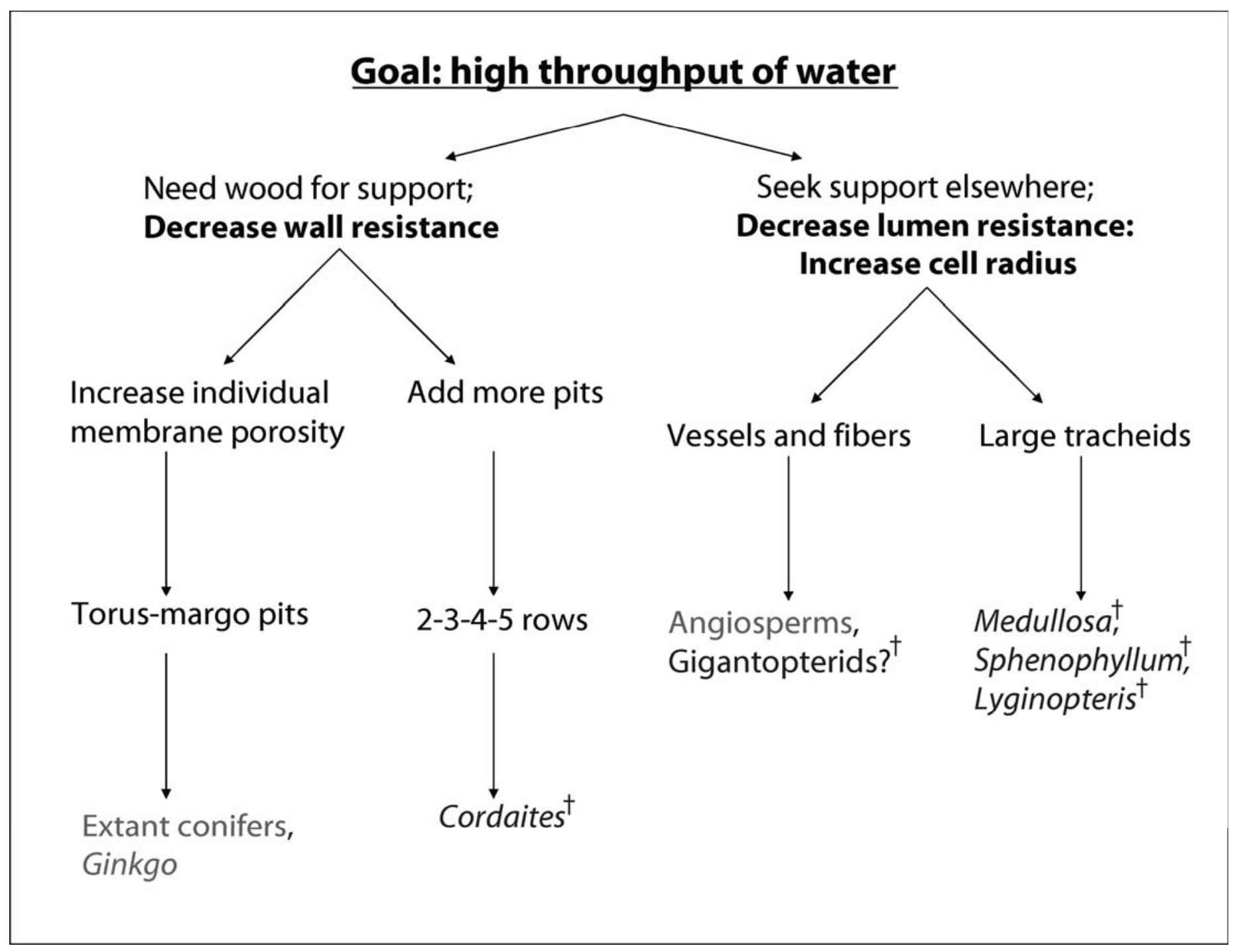


Wilson - 40

Table 1:

\begin{tabular}{|c|c|c|c|c|c|c|c|c|c|}
\hline Affinity & Genus & Species & Age & $\begin{array}{c}\text { Diameter } \\
\text { microns }\end{array}$ & $\begin{array}{c}\text { Length } \\
\mathrm{mm}\end{array}$ & Pit type & $\begin{array}{c}\text { Fpit } \\
\text { Fraction }\end{array}$ & $\begin{array}{c}\text { Pore diameter } \\
\text { nm }\end{array}$ & Reference \\
\hline Stem group seed plant & Medullosa & noei & Pennsylvanian & 141.7 & 24 & Circular-bordered & 0.4 & 40 & This study \\
\hline Stem group seed plant & Medullosa & primaeva & Pennsylvanian & 170 & 17.5 & Circular-bordered & 0.4 & 40 & This study \\
\hline Stem group seed plant & Medullosa & anglica & Pennsylvanian & 237 & 22 & Circular-bordered & 0.4 & 40 & This study \\
\hline Stem group seed plant & Medullosa & sp. & Pennsylvanian & 151 & 25.4 & Circular-bordered & 0.4 & 40 & This study \\
\hline Stem group seed plant & Medullosa & sp. & Pennsylvanian & 170 & 24 & Circular-bordered & 0.4 & 40 & This study \\
\hline Stem group seed plant & Medullosa & sp. & Pennsylvanian & 121 & 23 & Circular-bordered & 0.4 & 40 & This study \\
\hline Stem group seed plant & Medullosa & sp. & Pennsylvanian & 166 & 26 & Circular-bordered & 0.4 & 40 & This study \\
\hline Stem group seed plant & Medullosa & sp. & Pennsylvanian & 184 & 27 & Circular-bordered & 0.4 & 40 & This study \\
\hline Stem group seed plant & Medullosa & sp. & Pennsylvanian & 141 & 28 & Circular-bordered & 0.4 & 40 & This study \\
\hline Stem group seed plant & Lyginopteris & oldhamium & Pennsylvanian & 108 & 6.7 & Circular-bordered & 0.3 & 40 & This study \\
\hline Stem group seed plant & Lyginopteris & olchnamium & Pennsylvanian & 80.3 & 5.1 & Circular-bordered & 0.3 & 40 & This study \\
\hline Stem group seed plant & Lyginopteris & oldhamium & Pennsylvanian & 92.48 & 5.8 & Circular-bordered & 0.3 & 40 & This study \\
\hline Stem group seed plant & Lyginopteris & oldhramium & Pennsylvanian & 85.93 & 4.3 & Circular-bordered & 0.3 & 40 & This study \\
\hline Stem group seed plant & Lyginopteris & oldhamium & Pennsylvanian & 90.8 & 2.94 & Circular-bordered & 0.3 & 40 & This study \\
\hline Stem group seed plant & Lyginopteris & olch̆anium & Pennsylvanian & 72.91 & 4.36 & Circular-bordered & 0.3 & 40 & This study \\
\hline Stem group seed plant & Lyginopteris & oldhamium & Pennsylvanian & 80.35 & 4 & Circular-bordered & 0.3 & 40 & This study \\
\hline Stem group seed plant & Lyginopteris & oldh̆anitum & Pennsylvanian & 92.48 & 4.14 & Circular-bordered & 0.3 & 40 & This study \\
\hline Stem group seed plant & Lyginopteris & oldhamium & Pennsylvanian & 94.35 & 4.36 & Circular-bordered & 0.3 & 40 & This study \\
\hline Stem group seed plant & Lyginopteris & oldhamium & Pennsylvanian & 65.62 & 2.68 & Circular-bordered & 0.3 & 40 & This study \\
\hline Stem group conifer & Cordaites & sp. & Pennsylvanian & 25 & 4.25 & Circular-bordered & 0.2 & 40 & This study \\
\hline Stem group conifer & Cordaites & sp. & Pennsylvanian & 30 & 3.3 & Circular-bordered & 0.2 & 40 & This study \\
\hline Stem group conifer & Cordates & sp. & Pennsylvanian & 42.4 & 4.25 & Circular-bordered & 0.2 & 40 & This study \\
\hline Stem group conifer & Cordaites & sp. & Pennsylvanian & 18.55 & 2.25 & Circular-bordered & 0.2 & 40 & This study \\
\hline Stem group conifer & Cordaites & sp. & Pennsylvanian & 30.21 & 5 & Circular-bordered & 0.2 & 40 & This study \\
\hline Stem group gymnosperm & Callistophyton & poraxyloides & Pennsylvanian & 100 & 10 & Circular-bordered & 4 rows: 0.3 & 40 & Rothwell 1975 \\
\hline Extinct cycadeoid & Cycadeoidea & spp. & Lower Cretaceous & 55.5 & 23 & Scalariform ${ }^{\mathrm{C}}$ & Radial; 0.17 & 80 & Genus average from Ryberg et al. 2007 \\
\hline Extinct ginkgophyte & Ginkgo & beckii & Miocene & 48 & 29 & Torus-margo & 2 rows: 0.15 & 400 & Scott et al. 1962, this study \\
\hline Extant Ginkgo & Ginkgo & biloba & Recent & 40 & 28 & Torus-margo & 2 rows 0.15 & 400 & Bailey and Tupper, 1918; Scott et al. 1962 \\
\hline Extant Ginkgo & Ginkgo & biloba & Recent & 80 & 7 & Torus-margo & 0.15 & 400 & Scott et al 1962 , this study \\
\hline Extant cycad & cycas & thuarsii & Recent & 33 & 2.8 & Circular-bordered" & 0.15 & 40 & Terrazas 1991, rare scalariform \\
\hline Extant cyead & Microcycas & calocoma & Recent & 45 & 6 & Circular-bordered" & 0.15 & 40 & Chrysler 1926; half scalariform \\
\hline Extant cyead & Dioon & spinulosum & Recent & 32 & 6.8 & Circular-bordered" & 0.1 & 40 & Bailey and Tupper, 1918; Langdon 1920; Greguss 1968 \\
\hline Extant conifer & Picea & glauca & Recent & 37.6 & 3.33 & Torus-margo & 8.20 per tracheid: $0.085^{\circ}$ & 400 & Bannan $1965 ; \mathrm{Fp}$ from Pittermann et al. 2006 \\
\hline Extant conifer & Picea & engelmanni & Recent & 35.4 & 2.9 & Torus-margo & 0.075 & 400 & Bannan 1965; Fp from Pittermann et al. 2006 \\
\hline Extant conifer & Picea & engelmanni & Recent & 36.7 & 291 & Torus-margo & 0.075 & 400 & Bannan 1965; Fp from Pittermann et al. 2006 \\
\hline Extant conifer & Picea & mariana & Recent & 29.7 & 3.02 & Torus-margo & 0.071 & 400 & Bannan 1965; Fp from Pittermann et al. 2006 \\
\hline Extant conifer & Picea & mariana & Recent & 32.5 & 3.44 & Torus-margo & 0.071 & 400 & Bannan 1965; Fp from Pittermann et al. 2006 \\
\hline Extant conifer & Picea & glauca & Recent & 37.3 & 3.01 & Torus-margo & $0.085^{6}$ & 400 & Bannan 1965; Fp from Pittermann et al. 2006 \\
\hline Extant conifer & Pinus & strobus & Recent & 40.3 & 3.72 & Torus-margo & $0.085^{b}$ & 400 & Bannan 1965; Fp from Pittermann et al. 2006 \\
\hline Extant conifer & Pinus & strobus & Recent & 41 & 4.04 & Torus-margo & $0.085^{6}$ & 400 & Bannan 1965; Fp from Pittermann et al. 2006 \\
\hline Extant conifer & Pinus & resinosa & Recent & 37.4 & 3.36 & Torus-margo & $0.085^{b}$ & 400 & Bannan 1965; Fp from Pittermann et al. 2006 \\
\hline Extant conifer & Pinus & ponderosa & Recent & 38.6 & 3.33 & Torus-margo & $0.085^{b}$ & 400 & Bannan 1965; Fp from Pittermann et al. 2006 \\
\hline Extant conifer & Pinus & contorta & Recent & 33.3 & 3.01 & Torus-margo & 0.113 & 400 & Bannan 1965; Fp from Pittermann et al. 2006 \\
\hline Extant conifer & Pinus & contora & Recent & 35.4 & 2.9 & Torus-margo & 0.113 & 400 & Bannan 1965; Fp from Pittermann et al. 2006 \\
\hline Extant conifer & Pinus & banksiana & Recent & 34.9 & 3.14 & Torus-margo & $0.085^{\circ}$ & 400 & Bannan 1965; Fp from Pittermann et al. 2006 \\
\hline Extant conifer & Pinus & banksiana & Recent & 35.4 & 3.23 & Torus-margo & $0.085^{b}$ & 400 & Bannan 1965; Fp from Pittermann et al. 2006 \\
\hline Extant conifer & Psendotsuga & menziesii & Recent & 40.4 & 3.39 & Torus-margo & $0.085^{b}$ & 400 & Bannan 1965; Fp from Pittermann et al. 2006 \\
\hline Extant conifer & Cupressus & sargentii & Recent & 29.2 & 2.66 & Torus-margo & $0.085^{b}$ & 400 & Bannan 1965; Fp from Pittermann et al. 2006 \\
\hline Extant conifer & Cupressus & sargentii & Recent & 31.8 & 291 & Torus-margo & $0.085^{b}$ & 400 & Bannan 1965; Fp from Pittermann et al. 2006 \\
\hline Extant conifer & Sequoia & sempenivens & Recent & 43.7 & 4.12 & Torus-margo & 0.08 & 400 & Bannan 1965; Fp from Pittermann et al. 2006 \\
\hline Extant conifer & Junipenus & virginiana & Recent & 25.1 & 1.98 & Torus-margo & 0.11 & 400 & Bannan 1965; Fp from Pittermann et al. 2006 \\
\hline Extant conifer & Thija & occidentalis & Recent & 28.6 & 2.63 & Torus-margo & $0.085^{b}$ & 400 & Bannan 1965; Fp from Pittermann et al. 2006 \\
\hline Extant conifer & Metasequoia & glyptostroboides & Recent & 33 & 2 & Torus-margo & $0.085^{b}$ & 400 & Japels and Visscher, 2006 \\
\hline Extant conifer & Metasequoia & glyptostroboides & Recent & 48 & 4.5 & Torus-margo & $0.085^{b}$ & 400 & Bannan 1965 \\
\hline Extant vesselless angiosperm & Trochodendron & araloides & Recent & 12.81 & 1.89 & Sealariform & 0.18 & Large: 200 , Small: 20 & Bailey and Thompson, 1918; Hacke et al. 2007 \\
\hline Extant vesselless angiosperm & Tetracentron & sinense & Recent & 21.4 & 1.97 & Scalariform & 0.16 & Large: 200 , Small: 20 & Bailey and Thompson, 1918; Hacke et al. 2007 \\
\hline Extant vesselless angiosperm & Drimys & winteri & Recent & 29 & 4.3 & Circular-bordered & 0.077 & 40 & Bailey and Tupper, 1918; Carlquist 1988, Hacke et al. 2007 \\
\hline
\end{tabular}

These tracheids are reported to contain both scalariform and circular-bordered pits Value is average for conifers, from Pittermann et al. 2006 'See Methods 


\section{Literature Cited}

Anderson, J. M., H. M. Anderson, and A. R. I. Cruickshank. 1998. Late Triassic ecosystems of the Molteno Lower Elliot biome of southern Africa. Palaeontology 41:387-421.

Andrews, H. N., Jr. 1940. On the Stelar Anatomy of the Pteridosperms with Particular Reference to the Secondary Wood. Annals of the Missouri Botanical Garden 27(1):51-118.

Bailey, I. W., and W. W. Tupper. 1918. Size variation in tracheary cells: I. A comparison between the secondary xylems of vascular cryptogams, gymnosperms, and angiosperms. Proceedings of the American Academy of Arts and Sciences 54(2):149-204.

Ball, M. C., M. J. Canny, C. X. Huang, J. J. G. Egerton, and J. Wolfe. 2006. Freeze/thawinduced embolism depends on nadir temperature: the heterogeneous hydration hypothesis. Plant, Cell \& Environment 29(5):729-745.

Ball, M. C., J. Wolfe, M. Canny, M. Hofmann, A. B. Nicotra, and D. Hughes. 2002. Space and time dependence of temperature and freezing in evergreen leaves. Functional Plant Biology 29(11):1259-1272.

Bannan, M. W. 1965. Length Tangential Diameter and Length/Width Ratio of Conifer Tracheids. Canadian Journal of Botany 43(8):967-984.

Bateman, R. M., J. Hilton, and P. J. Rudall. 2006. Morphological and molecular phylogenetic context of the angiosperms: contrasting the 'top-down' and 'bottom-up' approaches used to infer the likely characteristics of the first flowers. Journal of Experimental Botany 57(13):3471-3503.

Batham, E. 1943. Vascular Anatomy of New Zealand species of Gunnera. Transactions of the Royal Society of New Zealand 73:7. 
Beck, A. L., and C. C. Labandeira. 1998. Early Permian insect folivory on a gigantopteriddominated riparian flora from north-central Texas. Palaeogeography, Palaeoclimatology, Palaeoecology 142(3-4):139-173.

Beck, C., R. Schmid, and G. Rothwell. 1982. Stelar morphology and the primary vascular system of seed plants. The Botanical Review 48(4):691-815.

Beck, C. B. 1960. Connection between Archaeopteris and Callixylon. Science 131(3412):15241525.

Beck, C. B. 1962. Reconstructions of Archaeopteris, and Further Consideration of its Phylogenetic Position. American Journal of Botany 49(4):373-382.

Beck, C. B. 1970. The Appearance of Gymnospermous Structure. Biological Reviews 45(3):379399.

Beck, C. B., and D. C. Wight. 1988. Progymnosperms. In C. Beck, ed. Origin and Evolution of Gymnosperms. Columbia University Press, New York.

Bond, W. J. 1989. The Tortoise and the Hare - Ecology of Angiosperm Dominance and Gymnosperm Persistence. Biological Journal of the Linnean Society 36(3):227-249.

Boyce, C. K., and A. H. Knoll. 2002. Evolution of Developmental Potential and the Multiple Independent Origins of Leaves in Paleozoic Vascular Plants. Pp. 70-100. Paleontological Society.

Buckley, T. N. 2005. The control of stomata by water balance. New Phytologist 168(2):275-291.

Burleigh, J. G., and S. Mathews. 2004. Phylogenetic signal in nucleotide data from seed plants: Implications for resolving the seed plant tree of life. American Journal of Botany 91(10):1599-1613. 
Carlquist, S. 1996. Wood, bark and stem anatomy of Gnetales: A summary. International Journal of Plant Sciences 157(6):S58.

Carlquist, S. 2001. Comparative Wood Anatomy. Springer, Berlin.

Choat, B., M. Ball, J. Luly, and J. Holtum. 2003. Pit membrane porosity and water stressinduced cavitation in four co-existing dry rainforest tree species. Plant Physiology 131(1):41-48.

Choat, B., T. W. Brodie, A. R. Cobb, M. A. Zwieniecki, and N. M. Holbrook. 2006. Direct measurements of intervessel pit membrane hydraulic resistance in two angiosperm tree species. American Journal of Botany 93(7):993-1000.

Choat, B., A. R. Cobb, and S. Jansen. 2008. Structure and function of bordered pits: new discoveries and impacts on whole-plant hydraulic function. New Phytologist 177(3):608626.

Choat, B., S. Jansen, M. A. Zwieniecki, E. Smets, and N. M. Holbrook. 2004. Changes in pit membrane porosity due to deflection and stretching: the role of vestured pits. Journal of Experimental Botany 55(402):1569-1575.

Chrysler, M. A. 1926. Vascular Tissues of Microcycas Calocoma. Botanical Gazette 82(3):233252.

Cichan, M. A. 1985. Vascular Cambium and Wood Development in Carboniferous Plants .2. Sphenophyllum-Plurifoliatum Williamson and Scott (Sphenophyllales). Botanical Gazette 146(3):395-403.

Cichan, M. A. 1986. Vascular Cambium and Wood Development in Carboniferous Plants .4. Seed Plants. Botanical Gazette 147(2):227-235. 
Cichan, M. A., and T. N. Taylor. 1984. A Method for Determining Tracheid Lengths in Petrified Wood by Analysis of Cross-Sections. Annals of Botany 53(2):219-226.

Comstock, J. P., and J. S. Sperry. 2000. Theoretical considerations of optimal conduit length for water transport in vascular plants. New Phytologist 148(2):195-218.

Crane, P. R. 1985. Phylogenetic Analysis of Seed Plants and the Origin of Angiosperms. Annals of the Missouri Botanical Garden 72(4):716-793.

Davis, S. D., J. S. Sperry, and U. G. Hacke. 1999. The relationship between xylem conduit diameter and cavitation caused by freezing. American Journal of Botany 86(10):13671372.

Delevoryas, T. 1955. The Medullosae: Structure and Relationships. Palaeontographica B 97(36):114-167.

DiMichele, W. A. 1979. Arborescent lycopods of Pennsylvanian age coals: Lepidophloios. Palaeontographica B 171:57-77.

DiMichele, W. A., and P. J. DeMaris. 1987. Structure and dynamics of a Pennsylvanian-age Lepidodendron forest; colonizers of a disturbed swamp habitat in the Herrin (No. 6) Coal of Illinois. Palaios 2(2):146-157.

DiMichele, W. A., and R. A. Gastaldo. 2008. Plant paleoecology in deep time. Annals of the Missouri Botanical Garden 95(1):144-198.

DiMichele, W. A., T. L. Phillips, and H. W. Pfefferkorn. 2006. Paleoecology of Late Paleozoic pteridosperms from tropical Euramerica. Journal of the Torrey Botanical Society 133(1):83-118.

Dixon, H. H. 1909. Transpiration and the ascent of sap. Progressus Rei Botanicae 3:1-66. Dixon, H. H. 1914. Transpiration and the Ascent of Sap in Plants. MacMillan and Co., London. 
Doyle, J. A. 2006. Seed ferns and the origin of angiosperms. Journal of the Torrey Botanical Society 133(1):169-209.

Doyle, J. A. 2008. Integrating Molecular Phylogenetic and Paleobotanical Evidence on Origin of the Flower. International Journal of Plant Sciences 169(7):816-843.

Edwards, D. 2003. Xylem in early tracheophytes. Plant Cell and Environment 26(1):57-72.

Ellerby, D., and A. Ennos. 1998. Resistances to fluid flow of model xylem vessels with simple and scalariform perforation plates. Journal of Experimental Botany 49(323):979-985.

Erasmus, T. 1976. On the anatomy of Dadoxylon arberi Seward with some remarks on the phylogenetical tendencies of its tracheid pits. Paleontologia Africana 19:127-133.

Esau, K. 1977. Anatomy of Seed Plants. John Wiley and Sons.

Feild, T. S., and L. Balun. 2008. Xylem hydraulic and photosynthetic function of Gnetum (Gnetales) species from Papua New Guinea. New Phytologist 177(3):665-675.

Feild, T. S., T. Brodribb, and M. Holbrook. 2002. Hardly a relict: Freezing and the evolution of vesselless wood in winteraceae. Evolution 56(3):464-478.

Feild, T. S., M. A. Zwieniecki, and N. M. Holbrook. 2000. Winteraceae evolution: An ecophysiological perspective. Annals of the Missouri Botanical Garden 87(3):323-334.

Feng, Z., J. Wang, and G.-L. Shen. 2008. Zalesskioxylon xiaheyanense sp. nov., a gymnospermous wood of the Stephanian (Late Pennsylvanian) from Ningxia, northwestern China. Journal of Asian Earth Sciences 33(3-4):219-228.

Florin, R. 1949. The morphology of Trichopitys heteromorpha Saporta, a seed plant of Paleozoic age, and the evolution of the female flowers in the Ginkgoinae. Acta Horti Bergiani 15:79-109. 
Florin, R. 1950. Upper Carboniferous and Lower Permian conifers. Botanical Review 16:258282.

Florin, R. 1951. Evolution in Cordaites and conifers. Acta Horti Bergiani 15:285-388.

Galtier, J. 1988. Morphology and Phylogenetic Relationships of Early Pteridosperms. In C. Beck, ed. Origin and Evolution of Gymnosperms. Columbia University Press, New York.

Galtier, J., and B. Meyer-Berthaud. 2006. The diversification of early arborescent seed ferns. Journal of the Torrey Botanical Society 133(1):7-19.

Glasspool, I., J. Hilton, M. E. Collinson, and W. Shi-Jun. 2004a. Defining the gigantopterid concept: a reinvestigation of Gigantopteris (Megalopteris) nicotianaefolia Schenck and its taxonomic implications. Palaeontology 47(6):1339-1361.

Glasspool, I. J., J. Hilton, M. E. Collinson, S.-J. Wang, and S. Li Cheng. 2004b. Foliar physiognomy in Cathaysian gigantopterids and the potential to track Palaeozoic climates using an extinct plant group. Palaeogeography, Palaeoclimatology, Palaeoecology 205(12):69-110.

Greguss, P. 1968. Xylotomy of the living cycads. Akademiai Kiado, Budapest, Hungary.

Greguss, P., and B. Balkay. 1972. Xylotomy of the living conifers. Akademiai Kiado, Budapest, Hungary.

Hacke, U. G., and J. S. Sperry. 2001. Functional and ecological xylem anatomy. Perspectives in Plant Ecology Evolution and Systematics 4(2):97-115.

Hacke, U. G., J. S. Sperry, T. S. Feild, Y. Sano, E. H. Sikkema, and J. Pittermann. 2007. Water transport in vesselless angiosperms: conducting efficiency and cavitation safety. International Journal of Plant Sciences 168(8):1113-1126. 
Hacke, U. G., J. S. Sperry, and J. Pittermann. 2004. Analysis of circular bordered pit function II. Gymnosperm tracheids with torus-margo pit membranes. American Journal of Botany 91(3):386-400.

Hacke, U. G., J. S. Sperry, W. T. Pockman, S. D. Davis, and K. A. McCulloch. 2001a. Trends in wood density and structure are linked to prevention of xylem implosion by negative pressure. Oecologia 126(4):457-461.

Hacke, U. G., J. S. Sperry, J. K. Wheeler, and L. Castro. 2006. Scaling of angiosperm xylem structure with safety and efficiency. Tree Physiology 26(6):689-701.

Hacke, U. G., V. Stiller, J. S. Sperry, J. Pittermann, and K. A. McCulloh. 2001b. Cavitation fatigue. Embolism and refilling cycles can weaken the cavitation resistance of xylem. Plant Physiology 125(2):779-786.

Hammel, H. T. 1967. Freezing of xylem sap without cavitation. Plant Physiology 42:55-66.

Jagels, R., and G. E. Visscher. 2006. A synchronous increase in hydraulic conductive capacity and mechanical support in conifers with relatively uniform xylem structure. American Journal of Botany 93(2):179-187.

Jansen, S., Y. Sano, B. Choat, D. Rabaey, F. Lens, and R. R. Dute. 2007. Pit membranes in tracheary elements of Rosaceae and related families: new records of tori and pseudotori. American Journal of Botany 94(4):503-514.

Kramer, P., and J. Boyer. 1995. Water Relations of Plants and Soils. Academic Press.

Lancashire, J. R., and A. R. Ennos. 2002. Modelling the hydrodynamic resistance of bordered pits. Journal of Experimental Botany 53(373):1485-1493.

Langdon, L. M. 1920. Stem Anatomy of Dioon spinulosum. Botanical Gazette 70(2):110-125. 
Li, H., and D. W. Taylor. 1998. Aculeovinea yunguiensis Gen. et Sp. Nov. (Gigantopteridales), a New Taxon of Gigantopterid Stem from the Upper Permian of Guizhou Province, China. International Journal of Plant Sciences 159:1023-1033.

Li, H., E. L. Taylor, and T. N. Taylor. 1996. Permian Vessel Elements. Pp. 188-189. American Association for the Advancement of Science.

Loepfe, L., J. Martinez-Vilalta, J. Piñol, and M. Mencuccini. 2007. The relevance of xylem network structure for plant hydraulic efficiency and safety. Journal of Theoretical Biology 247(4):788-803.

Maheshwari, H. K. 1972. Permian wood from Antarctica and revision of some Lower Gondwana wood taxa. Palaeontographica B 138:1-43.

Mamay, S. H., J. M. Miller, D. M. Rohr, and W. E. Stein, Jr. 1988. Foliar Morphology and Anatomy of the Gigantopterid Plant Delnortea Abbottiae, from the Lower Permian of West Texas. Pp. 1409-1433. Botanical Society of America.

McGhee, G. R. 1999. Theoretical Morphology: The Concept and Its Applications. Columbia University Press, New York.

Mosbrugger, V. 1990. The Tree Habit in Land Plants: A Functional Comparison of Trunk Constructions with a Brief Introduction into the Biomechanics of Trees. Springer-Verlag, Berlin.

Namboodiri, K. K., and C. B. Beck. 1968. A Comparative Study of the Primary Vascular System of Conifers. III. Stelar Evolution in Gymnosperms. Pp. 464-472. Botanical Society of America.

Niklas, K. J. 1992. Plant Biomechanics. University of Chicago Press, Chicago.

Niklas, K. J. 1997. The Evolutionary Biology of Plants. University of Chicago Press, Chicago. 
Niklas, K. J., and H. C. Spatz. 2004. Growth and hydraulic (not mechanical) constraints govern the scaling of tree height and mass. Proceedings of the National Academy of Sciences of the United States of America 101(44):15661-15663.

Pearce, R. S. 2001. Plant Freezing and Damage. Annnals of Botany 87(4):417-424.

Philippe, M., and M. K. Bamford. 2008. A key to morphogenera used for Mesozoic conifer-like woods. Review of Palaeobotany and Palynology 148(2-4):184-207.

Philippe, M., B. Gomez, V. Girard, C. Coiffard, V. Daviero-Gomez, F. Thevenard, J.-P. BillonBruyat, M. Guiomar, J.-L. Latil, J. Le loeuff, D. Néraudeau, D. Olivero, and J. Schlögl. 2008. Woody or not woody? Evidence for early angiosperm habit from the Early Cretaceous fossil wood record of Europe. Palaeoworld 17(2):142-152.

Pittermann, J., J. S. Sperry, U. G. Hacke, J. K. Wheeler, and E. H. Sikkema. 2005. Torus-margo pits help conifers compete with angiosperms. Science 310(5756):1924-1924.

Pittermann, J., J. S. Sperry, U. G. Hacke, J. K. Wheeler, and E. H. Sikkema. 2006a. Intertracheid pitting and the hydraulic efficiency of conifer wood: the role of tracheid allometry and cavitation protection. American Journal of Botany 93(9):1265-1273.

Pittermann, J., J. S. Sperry, J. K. Wheeler, U. G. Hacke, and E. H. Sikkema. 2006b. Mechanical reinforcement of tracheids compromises the hydraulic efficiency of conifer xylem. Plant Cell and Environment 29(8):1618-1628.

Rabaey, D., F. Lens, E. Smets, and S. Jansen. 2006. The Micromorphology of Pit Membranes in Tracheary Elements of Ericales: New Records of Tori or Pseudo-tori? Annals of Botany 98(5):943-951.

Raup, D. M. 1966. Geometric analysis of shell coiling; general problems. Journal of Paleontology 40(5):1178-1190. 
Raup, D. M. 1967. Geometric Analysis of Shell Coiling: Coiling in Ammonoids. Journal of Paleontology 41(1):43-65.

Rothwell, G. W. 1975. The Callistophytaceae (Pteridospermopsida): I. Vegetative structures. Palaeontographica B 151:171-196.

Rothwell, G. W. 1982. New interpretations of the earliest conifers. Review of Palaeobotany and Palynology 37(1-4):7-28.

Rothwell, G. W., G. Mapes, and M. R.H. 1997. Late Paleozoic conifers of North America: structure, diversity and occurrences. Review of Palaeobotany and Palynology 95(1-4):95113.

Rowe, N. P., and T. Speck. 2004. Hydraulics and mechanics of plants: novelty, innovation, and evolution. Pp. 297-326. In A. R. Helmsley, and I. Poole, eds. The Evolution of Plant Physiology. Elsevier Ltd, London.

Rowe, N. P., T. Speck, and J. Galtier. 1993. Biomechanical Analysis of a Paleozoic Gymnosperm Stem. Proceedings of the Royal Society of London Series B-Biological Sciences 252(1333):19-28.

Ryberg, P. E., E. L. Taylor, and T. N. Taylor. 2007. Secondary phloem anatomy of Cycadeoidea (Bennettitales). American Journal of Botany 94(5):791-798.

Sano, Y., and S. Jansen. 2006. Perforated Pit Membranes in Imperforate Tracheary Elements of Some Angiosperms. Annals of Botany 97(6):1045-1053.

Schulte, P. J., A. C. Gibson, and P. S. Nobel. 1987. Xylem Anatomy and Hydraulic Conductance of Psilotum-Nudum. American Journal of Botany 74(9):1438-1445.

Scott, D. H. 1902. On the primary structure of certain Palaeozoic stems with the Dadoxylon type of wood. Transactions of the Royal Society of Edinburgh 40:331-365. 
Scott, R. A., E. S. Barghoorn, and U. Prakash. 1962. Wood of Ginkgo in the Tertiary of Western North America. American Journal of Botany 49(10):1095-1101.

Serbet, R., and G. W. Rothwell. 1992. Characterizing the Most Primitive Seed Ferns. I. A Reconstruction of Elkinsia polymorpha. International Journal of Plant Sciences 153(4):602.

Sperry, J. S., and U. G. Hacke. 2004. Analysis of circular bordered pit function - I. Angiosperm vessels with homogenous pit membranes. American Journal of Botany 91(3):369-385.

Sperry, J. S., U. G. Hacke, T. S. Feild, Y. Sano, and E. H. Sikkema. 2007. Hydraulic consequences of vessel evolution in angiosperms. International Journal of Plant Sciences 168(8):1127-1139.

Sperry, J. S., U. G. Hacke, and J. Pittermann. 2006. Size and function in conifer tracheids and angiosperm vessels. Pp. 1490-1500.

Sperry, J. S., U. G. Hacke, and J. K. Wheeler. 2005. Comparative analysis of end wall resistivity in xylem conduits. Plant Cell and Environment 28(4):456-465.

Sperry, J. S., and T. Ikeda. 1997. Xylem cavitation in roots and stems of Douglas-fir and white fir. Tree Physiology 17(4):275-280.

Sperry, J. S., K. L. Nichols, J. E. M. Sullivan, and S. E. Eastlack. 1994. Xylem Embolism in Ring-Porous, Diffuse-Porous, and Coniferous Trees of Northern Utah and Interior Alaska. Ecology 75(6):1736-1752.

Sperry, J. S., and J. E. M. Sullivan. 1992. Xylem embolism in response to freeze-thaw cycles and water stress in ring-porous, diffuse-porous, and conifer species. Plant Physiology 100:605-613. 
Sperry, J. S., and M. T. Tyree. 1988. Mechanism of Water Stress-Induced Xylem Embolism. Plant Physiology 88(3):581-587.

Sperry, J. S., and M. T. Tyree. 1990. Water-Stress-Induced Xylem Embolism in 3 Species of Conifers. Plant Cell and Environment 13(5):427-436.

Steponkus, P. L. 1984. ROLE OF THE PLASMA MEMBRANE IN FREEZING INJURY AND COLD ACCLIMATION. Annual Review of Plant Physiology 35:543-584.

Stewart, W., and G. W. Rothwell. 1993. Paleobotany and the Evolution of Plants. Cambridge University Press.

Sucoff, E. 1969. Freezing of conifer xylem sap and the cohesion-tension theory. Physiologia Plantarum 22:424-431.

Taiz, L., and E. Zeiger. 2002. Plant Physiology. Sinauer Associates, Inc.

Taylor, T. N., and E. L. Taylor. 1993. The Biology and Evolution of Fossil Plants. Prentice Hall.

Taylor, T. N., E. L. Taylor, and M. Krings. 2008. Paleobotany: The Biology and Evolution of Fossil Plants. Academic Press.

Terrazas, T. 1991. Origin and Activity of Successive Cambia in Cycas (Cycadales). American Journal of Botany 78(10):1335-1344.

Tomlinson, P. B. 1990. The structural biology of palms. Clarendon Press ;

Oxford University Press, Oxford [England]

New York.

Tyree, M. T., and F. W. Ewers. 1991. Tansley Review No. 34. The Hydraulic Architecture of Trees and Other Woody Plants. New Phytologist 119(3):345-360. 
Tyree, M. T., S. Salleo, A. Nardini, M. A. Lo Gullo, and R. Mosca. 1999. Refilling of embolized vessels in young stems of laurel. Do we need a new paradigm? Plant Physiology 120(1):11-21.

Tyree, M. T., and J. S. Sperry. 1988. Do Woody-Plants Operate near the Point of Catastrophic Xylem Dysfunction Caused by Dynamic Water-Stress - Answers from a Model. Plant Physiology 88(3):574-580.

Tyree, M. T., and J. S. Sperry. 1989. Vulnerability of Xylem to Cavitation and Embolism. Annual Review of Plant Physiology and Plant Molecular Biology 40:19-38.

van den Honert, T. H. 1948. Water transport in plants as a catenary process. Discussions of the Faraday Society 3(1):146-153.

Veres, J. S. 1990. Xylem Anatomy and Hydraulic Conductance of Costa Rican Blechnum Ferns. American Journal of Botany 77(12):1610-1625.

Vogel, S. 1994. Life in Moving Fluids. Princeton University Press.

Wheeler, J. K., J. S. Sperry, U. G. Hacke, and N. Hoang. 2005. Inter-vessel pitting and cavitation in woody Rosaceae and other vesselled plants: a basis for a safety versus efficiency tradeoff in xylem transport. Plant Cell and Environment 28(6):800-812.

Wilkinson, H. P. 2000. A revision of the anatomy of Gunneraceae. Botanical Journal of the Linnean Society 134(1-2):233-266.

Wilson, J. P., A. H. Knoll, N. M. Holbrook, and C. R. Marshall. 2008. Modeling fluid flow in Medullosa, an anatomically unusual Carboniferous seed plant. Paleobiology 34(4):472493.

Wnuk, C., and H. W. Pfefferkorn. 1984. The Life Habits and Paleoecology of Middle Pennsylvanian Medullosan Pteridosperms Based on an Insitu Assemblage from the 
Bernice Basin (Sullivan County, Pennsylvania, USA). Review of Palaeobotany and Palynology 41(3-4):329-351.

Zimmermann, M. H. 1983. Xylem Structure and the Ascent of Sap. Springer-Verlag, Berlin. 